\title{
A Moving Target: Property Owners' Duty to Prevent Criminal Acts on the Premises
}

by Deborah J. La Fetra ${ }^{1}$

\section{PREMISES LIABILITY FOR THIRD-PARTY VIOLENCE: WHAT IS THE STANDARD FOR IMPOSING A DUTY?}
A. "Totality of the Circumstances" Versus "Prior Similar Acts"
B. From No Duty to Liability in Sixty Seconds

II. TWISTS IN THE TALE
A. Twist \#1: The "Tragically Bizarre" Event Leading to Injury
B. Twist \#2: Tenant-on-Tenant Crime

1. Courts Distinguish Between Crimes Committed by Intruders and by Those Authorized To Be on the Premises

2. Duty to Monitor Potential and Existing Tenants Places Landlords in a Catch-22

\section{Tenants Have a Right to Keep Certain Information Private}

4. Statutes Prohibit Landlords from Refusing to Rent to Potential Tenants on the Basis of Mental Illness that Could Result in Criminal Activity

C. Twist \#3: The Impact of Gang Violence

\section{CONCLUSION}

\footnotetext{
${ }^{1}$ Principal Attorney, Pacific Legal Foundation. J.D. 1990, University of Southern California Law Center; B.A. 1987 Claremont McKenna College. The author filed amicus briefs under the auspices of Pacific Legal Foundation's Free Enterprise Project in each of the California Supreme Court premises liability cases handed down in 2004-05. The author wishes to thank colleagues Timothy Sandefur and Anthony T. Caso for their thoughtful comments.
} 
The basic scenario for cases involving property owner responsibility for criminal acts that occur on the premises is this: A business invites members of the public to come onto its property. Jane Doe, a member of the public, legitimately enters the property. For jurisdictions that keep track of such designations, she would be an invitee. ${ }^{2}$ While on the property, Ms. Doe is attacked and injured. Her assailant either flees or is caught and convicted. Regardless of whether the attacker remains at large or in jail, Ms. Doe sues the property owner on a theory of premises liability. She would argue that the property owner should have known that there was a likelihood of an attack and should have taken steps to prevent it. The courts will decide whether the property owner owes a duty to the plaintiff and is liable for her injuries based on the foreseeability of the attack.

Foreseeability is the key because it is an element both of duty and of causation. ${ }^{3}$ In defining the foreseeability analysis as it pertains to duty, the California Supreme Court explained:

[A] court's task - in determining "duty" - is not to decide whether a particular plaintiff's injury was reasonably foreseeable in light of a particular defendant's conduct, but rather to evaluate more generally whether the category of negligent

${ }^{2} C f$. Kermarec v. Compagnie Generale Transatlantique, 358 U.S. 625, 630-32, 79 S.Ct. 406, 409-410, 3 L.Ed.2d 550, 554-55 (1959) (discussing blurring between classifications of visitors and noting that "the common law has moved, unevenly and with hesitation, towards 'imposing on owners and occupiers a single duty of reasonable care in all the circumstances."'). See also Hall v. Cagle, 773 So.2d 928, 932 (Miss. 2000) (McRae, J., concurring) (listing the seminal decisions in various jurisdictions that have eliminated one or more classification of visitor).

${ }^{3}$ In premises liability cases, foreseeability is a factor in the analysis of (1) whether the property owner had a duty to the injured person, and (2) whether the alleged failures of the property owner to provide adequate protection caused the injury. Unfortunately, courts frequently fail to distinguish which type of foreseeability they are considering and also frequently cite duty cases in the midst of a causation analysis and vice versa. 
conduct at issue is sufficiently likely to result in the kind of harm experienced that liability may appropriately be imposed on the negligent party. ${ }^{4}$

This dual role complicates matters because courts sometimes do not identify whether their focus is on duty or causation and courts even more frequently use duty-foreseeability cases as precedent to support duty-causation holdings and vice versa. ${ }^{5}$ Duty-foreseeability cases center on the question of whether the property owner should have provided security measures that would have reduced the probability of a certain type of criminal attack. Duty-causation cases consider whether the property owners' adoption of the duty-required security measures would have prevented the actual attack that precipitated the lawsuit.

This article addresses a variety of duty-foreseeability cases from around the country, paying particular attention to the three major decisions issued by the California Supreme Court in 2004- $05^{6}$ Part I of this article traces the various pendulum swings of the California Supreme Court as it moves from a strongly pro-plaintiff to a moderately pro-defendant back to a

${ }^{4}$ Thing v. LaChusa, 48 Cal. 3d 644, 652 n.3, 771 P.2d 814, 819 n.3, 257 Cal. Rptr. 865, 870 n.3 (1989) (quoting Ballard v. Uribe, 41 Cal.3d 564, 573 n.6, 715 P.2d 624, 630 n.6 (1986)).

${ }^{5}$ Both Ann M. v. Pacific Plaza Shopping Ctr., 6 Cal.4th 666, 25 Cal. Rptr. 2d 137, 863 P.2d 207 (1993), and Sharon P. v. Armen, 21 Cal. 4th 1181, 989 P.2d 121, 91 Cal. Rptr.2d 35 (1999), were "duty-foreseeability" cases. However, they were cited as authority in Saelzler v. Advanced Group 400, 25 Cal.4th 763, 23 P.3d 1143, 107 Cal. Rptr. 2 d 617 (2001), which was a "causation-foreseeability" case.

${ }^{6}$ Wiener v. Southcoast Child Care Center, 32 Cal. 4th 1138, 88 P.3d 517, 12 Cal. Rptr. 615 (2004); Delgado v. Trax Bar \& Grill, 36 Cal. 4th 224, 113 P.3d 1159, 30 Cal. Rptr.3d 145 (2005); and Morris v. De La Torre, 36 Cal. 4th 260, 113 P.3d 1182, 30 Cal. Rptr. 3d 173 (2005). The California Supreme Court also issued "grant and hold" orders in Avila v. Jado Properties (court granted review pending decision in Delgado); and Kadish v. Jewish Community Center (court granted review pending decision in Wiener). It is important to note that all these cases turned on the question of duty, not causation. While the different concepts do overlap to some extent, particularly as regards foreseeability, this Article treats them as distinct. 
moderately pro-plaintiff definition of duty in premises liability cases. ${ }^{7}$ The article particularly considers the impact of a shifting approach to duty, in which the legal analysis of foreseeability changes depending on whether the criminal assault is in the future, imminent or ongoing. ${ }^{8}$

The article then examines a number of "twists in the tale" that make depart from the standard scenario described above. Twist \#1 is the tragically bizarre criminal act that causes injury. Twist \#2 considers whether a landlord has a duty to prevent tenant-on-tenant crime, e.g., where both the attacker and victim were authorized to be on the premises. Twist \#3 considers whether gang violence impacts the analysis of foreseeability in a different way than "random" crime. $^{9}$ Taken together, these twists demonstrate that courts frequently find themselves in the untenable position of second guessing the reasonableness of property owners and their employees during an ongoing criminal act. Viewing the incidents in hindsight, judges tend to

${ }^{7}$ See infra at notes ______ and accompanying text. The emphasis on California jurisprudence is warranted as the state has a deserved reputation for being ahead of the curve. For example, in Foster-Gardner, Inc. v. National Union Fire Ins. Co., 18 Cal. 4th 857, 959 P.2d 265, 77 Cal. Rptr. 2d 107 (Cal. 1998), the California Supreme Court adopted the minority view that insurers do not have a duty to defend administrative agency proceedings, declaring that the term "suit"means a legal proceeding initiated by the filing of a lawsuit, as opposed to the initiation of administrative proceedings. This ruling was then followed by the Ninth Circuit Court of Appeals (Granite Mgmt. Corp. v. Aetna Cas. \& Sur. Co., 37 Fed. Appx. 262, 2002 U.S. App. LEXIS 10836 (2002)), and the State of Illinois (W.C. Richards Co. v. Hartford Accident \& Indem. Co., 311 Ill. App. 3d 218, 724 N.E.2d 63 (1999)). See also, Victoria L. Rees, AIDSphobia: Forcing Courts to Face New Areas of Compensation for Fear of a Deadly Disease, 39 VILL. L. REV. 241, 249 n. 41 (1994), noting that the trend towards recovery for emotional distress without accompanying physical injury began with the California Supreme Court's decision in Dillon v. Legg, 68 Cal. 2d 728, 69 Cal. Rptr. 72, 441 P.2d 912 (Cal. 1968), which established the standard for recovery by a third party who witnessed the negligent injury of another. A subsequent case, Molien v. Kaiser Foundation Hospitals, 27 Cal. 3d 916, 167 Cal. ineRptr. 831, 616 P.2d 813 (Cal. 1980), established the California Supreme Court as a trendsetter in this area of recovery.

\footnotetext{
${ }^{8}$ See infra at notes ______ and accompanying text.

${ }^{9}$ See infra at notes ______ and accompanying text.
} 
expand the landowners' duty, to the detriment of certainty and fairness in the law.

\section{I.}

\section{PREMISES LIABILITY FOR THIRD-PARTY VIOLENCE: WHAT IS THE STANDARD FOR IMPOSING A DUTY?}

\section{A. "Totality of the Circumstances" Versus "Prior Similar Acts"}

Jurisdictions generally apply one of two possible strains of analysis to determine whether a landowner has a duty to protect individuals from third-party criminal assaults: "totality of the circumstances" or "prior similar acts." The courts that apply the "totality of the circumstances" analysis

generally do not distinguish between crimes against property and crimes against persons, reasoning that property crimes can easily escalate to violent crimes. Those jurisdictions that apply the totality of the circumstances rule consider all prior criminal incidents occurring on the landowner's premises and adjacent properties, whether similar or not, as well as other types of evidence such as the nature, location, condition, and the architectural design of the landowner's property. $^{10}$

The "prior similar acts" rule states that "in the absence of prior similar incidents, an owner of land is not bound to anticipate the criminal activities of third persons, particularly where the wrongdoer was a complete stranger to both the landowner and the victim and where the criminal activity leading to the injury came about precipitously.",11

\footnotetext{
${ }^{10}$ Clohesy v. Food Circus Supermarkets, Inc., 149 N.J. 496, 509, 694 A.2d 1017, 1024 (N.J. 1997).

${ }^{11}$ Isaacs v. Huntington Memorial Hosp., 38 Cal.3d 112, 125, 211 Cal. Rptr. 356, 361, 695 P.2d 653, 658 (Cal.1985) (quoting Wingard v. Safeway Stores, Inc., 176 Cal. Rptr. 320 (Cal.Ct.App. 1981)).
} 
In California, one of the leading jurisdictions in this area of the law, the court has swung from the broadest scope of potential liability for landowners to the more restrictive "prior similar acts" doctrine, and then, most recently, issued decisions describing a sliding scale approach to duty and foreseeability that leave landowners very unclear as to the standard that will be applied and under what circumstances. The scope of the duty to provide protection from foreseeable third party crime is "determined in part by balancing the foreseeability of the harm against the burden of the duty to be imposed." ${ }^{12}$ If the burden of preventing future harm in a particular case is great, then a high degree of foreseeability is required. ${ }^{13}$ However, if there are "strong policy reasons for preventing the harm, or the harm can be prevented by simple means, a lesser degree of foreseeability may be required." 14 Thus, the duty is "determined by a balancing of 'foreseeability' of the criminal acts against the 'burdensomeness, vagueness, and efficacy' of the proposed security measures." ${ }^{\prime 15}$

The swiftly swinging pendulum was at its most pro-plaintiff position in Bigbee v. Pacific Tel. \& Tel. Co. ${ }^{16}$ identified by Professors Michael Rustad and Thomas Koenig as "[t]he highwater mark of California's judicial tort expansionism." ${ }^{17}$ Specifically with regard to the concept

${ }^{12}$ Ann M., 6 Cal. 4th at 678, 25 Cal. Rptr. 2d at 145, 863 P.2d at 215 (citing and "refining" Isaacs v. Huntington Memorial Hospital, 38 Cal. 3d 112, 125 (1985)).

${ }^{13} \mathrm{Id}$.

${ }^{14}$ Id. (citation omitted).

${ }^{15}$ Id. at 679, 25 Cal. Rptr. 2d at 145, 863 P.2d at 215 (citation omitted).

${ }^{16} 34$ Cal. 3d 49, 665 P.2d 947, 192 Cal. Rptr. 857 (1983).

${ }^{17}$ Michael L. Rustad and Thomas H. Koenig, Taming the Tort Monster: The American Civil Justice System as a Battleground of Social Theory, 68 BROOKLYN L. REV. 1, 48 (2002). During the expansionist era, the California high court led the way in carving out new categories of plaintiff recovery in nearly every 
of duty, the authors note that the California Supreme Court

employed the concept of duty to expand, rather than retract, liability. This was the first court to recognize new special relationships that imposed positive duties upon defendants. ...

California also expanded liability to bystanders in negligent infliction of emotional distress cases. ... In another first, California imposed negligence liability for the content of a radio broadcast. ${ }^{18}$

Yet for all these firsts, the authors identify Bigbee v. Pacific Telephone \& Telegraph Co., a case in which the victim of a drunk driver sued the owner of the telephone booth in which he was struck, as a particularly baneful expansion of tort liability. ${ }^{19}$ The majority opinion in that case stated:

It is of no consequence that the harm to plaintiff came about through the negligent or reckless acts of [drunk driver] Roberts. "If the likelihood that a third person may act in a particular manner is the hazard or one of the hazards which makes the actor negligent, such an act whether innocent, negligent, intentionally tortious, or criminal does not prevent the actor from being liable for harm caused thereby." 20

This language from Bigbee stands out as a jarring anachronism. It is of "no consequence" that Bigbee's injuries would not have occurred but for being hit by a drunk driver?! Such a statement is utterly inconsistent with Rowland v. Christian's list of relevant factors:

[T]he degree of certainty that the plaintiff suffered injury, the closeness of the connection between the defendant's conduct and the injury suffered, the moral

corner of tort law. California recognized new remedies for non-pecuniary injuries, loss of consortium, prenatal injuries, punitive damages, medical monitoring, wrongful life and wrongful birth. Plaintiffs were also permitted to recover against co-defendants under the novel theory of concerted action. Id. at 45-46.

${ }^{18} I d$. at $46-47$.

${ }^{19} I d$. at 48.

${ }^{20}$ Bigbee, 34 Cal. 3d at 58-59, 665 P.2d at 952, 192 Cal. Rptr. at 862 (quoting Restatement (Second) of Torts $§ 449$ (1965)). 
blame attached to the defendant's conduct, the policy of preventing future harm, the extent of the burden to the defendant and consequences to the community of imposing a duty to exercise care with resulting liability for breach, and the availability, cost, and prevalence of insurance for the risk involved. ${ }^{21}$

Specifically, the intentional criminal act of a third-party bears on the closeness of the connection between the defendant and the injuries sustained by the plaintiff; the moral blame of the defendant; and the extent of the burden to the defendant and the consequences to the community.

Two years later, the court adopted the "totality of the circumstances" approach of Isaacs v. Huntington Memorial Hospital. ${ }^{22}$ There, the court held that prior incidents, whether similar or not, would be one type of evidence of foreseeability, and other types of evidence may also be relevant, such as "the nature, condition and location of the defendant's premises." ${ }^{23}$ This decision was immediately criticized, the most fundamental problem being simply that property owners could have no way of knowing whether they had a duty or what might be required to fulfill that duty. ${ }^{24}$ Everything would be judged with the 20/20 vision of hindsight. As Peter Huber explained, "Foreseeing the future depends largely on remembering the past. This means that an accident involving bizarre behavior becomes foreseeable as soon as it has happened." ${ }^{25}$ Huber focuses on the judicial unpredictability associated with defining what is "foreseeable":

\footnotetext{
${ }^{21}$ Rowland v. Christian, 69 Cal. 2d 108, 113, 443 P.2d 561, 564, 70 Cal. Rptr. 97, 100 (1968).

${ }^{22} 38$ Cal. 3d at 129, 211 Cal. Rptr. at 364, 695 P.2d at 661.

${ }^{23} \mathrm{Id}$.

${ }^{24}$ See Lefmark Management Co. v. Old, 946 S.W.2d 52, 56 (Tex. 1997) (Owen, J., concurring) ("[I] in an increasingly violent society, in which crime may be visited upon virtually anyone at any time or place, there should be some certainty and predictability about what actions will satisfy the duty of care.").

${ }^{25}$ Peter Huber, Liability: The Legal Revolution and its Consequences58 (1988).
} 
"In the end, the difference between the foreseeable and the unforeseeable in the courts turned out to be very much like the difference (as defined by legendary National League umpire Bill Klem) between a ball and a strike. There wasn't any until the umpire had called it."26

As a practical result, the "totality of the circumstances" standard meant that the power to determine questions of duty was transferred from judges to juries and that "the law was what an individual group of jurors said it was." 27 Moreover, any case which goes to a jury under general instructions on the foreseeability of a heinous crime almost invariably results in a verdict for the plaintiff. $^{28}$ With hindsight, juries inevitably find that more security should have been employed since the security provided was in fact inadequate. ${ }^{29}$ It is precisely for this reason that most cases

${ }^{26} I d$. at 77. As an example of the type of uncertainty engendered by "totality of the circumstances," the experience of premises liability cases in Massachusetts is instructive. In some cases, such as Sharpe v. Peter Pan Bus Lines, Inc., 519 N.E.2d 1341 (Mass. 1988) (unprovoked stabbing in the back of a girl engaged in conversation with her friends in a bus terminal in daytime), and Flood v. Southland Corp., 616 N.E.2d 1068, 1075 (Mass. 1993) (stabbing occurred during drunken horseplay between two teenaged boys outside a 7-Eleven), the courts found even the most bizarre instances of criminal activity to be foreseeable; whereas in other cases, such as Foley v. Boston Housing Authority, 555 N.E.2d 234, 236-37 (Mass. 1990) (manager of a rough housing project, who was repeatedly threatened and harassed, was "suckerpunch[ed]" by an employee over a paycheck dispute), a relatively common type of criminal assault was determined to be unforeseeable under the circumstances. See Daryl J. Lapp and Maria A. Patrizio, Premises Liability in Massachusetts: The Evolution of Foreseeability, 29 NEW ENG. L. REV. 33, 36 (1994).

${ }^{27}$ Stephen D. Sugarman, Judges as Tort Law Un-Makers: Recent California Experience with “New” Torts, 49 DePAUl L. REV. 455, 470 (1999).

${ }^{28}$ Uri Kaufman, When Crime Pays: Business Landlords' Duty to Protect Customers from Criminal Acts Committed on the Premises, 31 So. TEX. L. REV. 89, 105-06 (1990).

${ }^{29} 7735$ Hollywood Blvd. Venture v. Superior Court, 116 Cal. App. 3d 901, 905, 172 Cal.Rptr. 528, 530 (1981) ("It would be intolerable and grossly unfair to permit a lay jury, after the fact, to determine in any case that security measures were 'inadequate,' especially in light of the fact that the decision would always be rendered in a case where the security had in fact proved to be inadequate."). 
surviving a motion for summary judgment result in large settlements for the plaintiffs. ${ }^{30}$

Next came Ann M. v. Pacific Plaza Shopping Ctr., in which the California Supreme Court determined that the plaintiff failed to establish the degree of foreseeability necessary to require the duty to provide the security guards in common areas. The court held that violent criminal assaults were not sufficiently foreseeable to impose a duty on the defendants to hire security patrols. This decision was based on several factors: (1) the lack of evidence that defendants had notice of prior similar incidents occurring on the premises, (2) evidence of other criminal conduct on the premises was not similar in nature to the violent assault suffered by Ann M., and (3) that neither evidence of the crime rate in the surrounding neighborhood nor evidence that transients were present on the premises was sufficient to establish a high degree of foreseeability. ${ }^{31}$ Because of the significant monetary and social burdens of hiring of security guards, the California Supreme Court held that a high degree of foreseeability was required, which could "rarely, if ever, ... be proven in the absence of prior similar incidents of violent crime on the landowner's premises." ${ }^{, 32}$ Ann M. diplomatically stated that it "refined" Isaacs, ${ }^{33}$ but in fact Ann M. apparently undercut the precepts on which the earlier decision was based. Justice Mosk's dissent in Ann M. acknowledges as much. ${ }^{34}$ Ann $M$. recognized the problems inherent in the "totality of the circumstances" analysis, noting that other courts and commentators had found the Isaacs standard inequitable, hard to apply, confusing, and

\footnotetext{
${ }^{30}$ Kaufman, When Crime Pays, 31 So. TEX. L. REV. at 100.

${ }^{31}$ Ann M., 6 Cal. 4th at 679-80, 25 Cal. Rptr. 2d at 146, 863 P.2d at 216.

${ }^{32}$ Id. at 679, 25 Cal. Rptr. 2d at 145, 863 P.2d at 215.

${ }^{33}$ Id. at 678, 25 Cal. Rptr. 2d at 145, 863 P.2d at 215 .

${ }^{34}$ Id. at 680-81, 25 Cal. Rptr. 2d at 146, 863 P.2d at 216 (Mosk, J., dissenting).
} 
unworkable in a society endemic with random, violent crime. ${ }^{35}$

The California court's Ann M. decision, retreating from "totality of the circumstances," proved persuasive in many other states. For example, in Posecai v. Wal-Mart Stores, Inc., ${ }^{36}$ the Louisiana Supreme Court rejected the "totality of the circumstances" test in favor of the Ann M. approach for solid policy reasons:

We agree that a balancing test is the best method for determining when business owners owe a duty to provide security for their patrons. The economic and social impact of requiring businesses to provide security on their premises is an important factor. Security is a significant monetary expense for any business and further increases the cost of doing business in high crime areas that are already economically depressed. Moreover, businesses are generally not responsible for the endemic crime that plagues our communities, a societal problem that even our law enforcement and other government agencies have been unable to solve. At the same time, business owners are in the best position to appreciate the crime risks that are posed on their premises and to take reasonable precautions to counteract those risks.

Other jurisdictions concur. ${ }^{37}$ The Minnesota Supreme Court did not adopt the Ann M. test per se, but factored into its analysis one of the significant policy considerations that underlie that decision:

[A] duty to protect against the devious, sociopathic, and unpredictable conduct of criminals does not lend itself easily to an ascertainable standard of care uncorrupted by hindsight nor to a determination of causation that avoids speculation. There is a difference between a landowner's duty to sand a slippery step on his premises and his duty to contain a slippery criminal. In the latter instance, the landowner is being asked to take defensive measures against a third

${ }^{35}$ Id. at 676-78, 25 Cal. Rptr. $2 d$ at 144-45, 863 P.2d at 214-15.

${ }^{36} 752$ So. $2 d 762,768$ (La. 1999).

${ }^{37}$ See, e.g., McClung v. Delta Square Ltd. P'ship, 937 S.W.2d 891, 900 (Tenn. 1996) (adopting a balancing test similar to Ann $M$. after finding that the "totality of the circumstances" standard is "too broad a standard, effectively imposing an unqualified duty to protect customers in areas experiencing any significant level of criminal activity"); Allright San Antonio Parking Inc. v. Kendrick, 981 S.W.2d 250, 256 (Tex. App. 1998) (specifically adopting the reasoning of Ann M.). 
person not within his control, indeed, someone who tries to outwit any defenses. Yet when a crime does occur, the tendency is not to consider whether the defendant had taken reasonable precautions but what further security measures would have prevented the crime that did occur and to make these further safeguards, ex post facto, the applicable standard of care. ${ }^{38}$

Mississippi explicitly refused to adopt the "totality of the circumstances" approach in Corley v. Evans: ${ }^{39}$ Though the court mistakenly considered Ann M. to be little more than "partial retreat" from the Isaacs approach, it then rejected any version of "totality of the circumstances." ${ }^{, 40}$ Maryland quotes Ann $M$. at length and adopts both its policies and the balancing test. $^{41}$

These cases share a common concern with making a property owner the insurer of the safety of anyone who happens to be on the premises. If the courts are concerned about spreading the cost of injuries sustained due to criminal acts over a broader class of victims, then the most logical response would be to spread the cost among members of the whole community. ${ }^{42}$ As many courts have noted, crime is a societal problem beyond the control of individual landowners. ${ }^{43}$

${ }^{38}$ See Erickson v. Curtis Inv. Co., 447 N.W.2d 165, 169 (Minn. 1989).

${ }^{39} 835$ So. 2 d 30, 39-40 (Miss. 2003).

${ }^{40} \mathrm{Id}$.

${ }^{41}$ See, e.g., Smith v. Dodge Plaza Ltd. P'ship, 148 Md.App. 335, 352-53, 811 A.2d 881, 891-92 (Md. App. 2002) (finding no duty to prevent shooting where only prior incidents involved fisticuffs), cert. denied, 374 Md. 84 (2003).

${ }^{42}$ George Bair South, The Duty to Protect Customers from Criminal Acts Occurring off the Premises: The Watering-Down of the "Prior Similar Incidents" Rule, 19 HOFSTRA L. REV. 1271, 1279 (1991).

${ }^{43}$ See e.g., Ann M., 6 Cal. 4th at 678, 25 Cal. Rptr. 2d at 145-46, 863 P.2d at 215-16; Waters v. New York City Hous. Auth., 69 N.Y.2d 225, 228- 231, 513 N.Y.S.2d 356, 505 N.E.2d 922) (the owner of a housing project who failed to keep the building's door locks properly 
In Sharon P. v. Arman, Ltd., ${ }^{44}$ the California Supreme Court held that the defendant landlord had no duty to provide security guards in an underground commercial parking garage because the sexual assault on the plaintiff was not foreseeable. The Court did not demand that prior incidents be identical, but found that evidence of multiple robberies at the bank on the first floor of the building, several hundred crimes (including two rapes) in the general neighborhood, and of vagrants sleeping and urinating in or around the garage prior to the assault was not enough for a reasonable person to foresee the type of assault that occurred. ${ }^{45}$ The Court found it significant that none of the bank robberies had involved violent attacks, and held that this fact, even when considered with the other evidence, did not establish the high degree of foreseeability necessary to justify the "significant burden" of imposing a duty to provide security guards in the garage. $^{46}$

Ann M. and Sharon P. did not require proof of prior identical acts to warrant finding a duty to protect. The sheer difficulty of weighing various types of criminal activity to determine foreseeability is one reason why the question is deemed a matter of law for the court to decide,

repaired did not owe a duty to a passerby to protect her from being dragged off the street into the building and assaulted because imposing such a duty on landowners would do little to minimize crime, and the social benefits to be gained did "not warrant the extension of the landowner's duty to maintain secure premises to the millions of individuals who use the sidewalks of New York City each day and are thereby exposed to the dangers of street crime."); Hutchins v. 1001 Fourth Ave. Associates, 116 Wash.2d 217, 236-37, 802 P.2d 1360, 1370-71 (Wash. 1991) ("there is unfairness in placing the burden of ensuring the safety of the citizenry upon occupants of land adjacent to public ways because protection of the public in general is a duty allocated to the government").

${ }^{44} 21$ Cal. 4th 1181, 989 P.2d 121, 91 Cal. Rptr. 2d 35 (1999).

${ }^{45}$ Sharon P., 21 Cal. 4th at 1186, 1191, 1194-95, 989 P.2d at 123-24, 127, 129-30, 91 Cal. Rptr. 2d at 37-38, 41, 44.

${ }^{46} I d$. at 1191, 1195, 989 P.2d at 127, 91 Cal. Rptr. $2 d$ at 41. 
rather than left to more unpredictable juries. When the court uses prior criminal activity to determine foreseeability and, hence, liability, one of the major issues is whether or not the prior crimes resembled closely enough the criminal activity generating the claimed injury. The Georgia Supreme Court addressed this issue in Sturbridge Partners, Ltd. v. Walker, ${ }^{47}$ which requires the court to:

inquire into the location, nature and extent of prior criminal activities and their likeness, proximity or other relationship to the crime in question. ... While the prior criminal activity must be substantially similar to the particular crime in question, that "does not mean identical. ... '[What] is required is that the prior [incident] be sufficient to attract the [landlord's] attention to the dangerous condition which resulted in the litigated [incident].

The court's adoption of a sliding scale to measure foreseeability-and thus determine whether a duty exists-was premised on a view of duty as a flexible concept that courts must determine by balancing the degree of foreseeability with the degree of potential harm. ${ }^{49}$

\section{B. From No Duty to Liability in Sixty Seconds}

In California, the question of duty became more complicated in Delgado v. Trax Bar \& $G r i l l,{ }^{50}$ which backtracked from the demanding heightened scrutiny requirements of Ann M. and

${ }^{47} 482$ S.E.2d 339 (Ga. 1997).

${ }^{48}$ Id. at 341 (citation omitted). See also Hendrickson v. Georgia Power Co., 80 F. Supp. 2d 1374, 1381 (M.D. Ga. 2000) (relying on Sturbridge).

${ }^{49}$ See Donna Lee Welch, Ann M. v. Pacific Plaza Shopping Center: The California Supreme Court Retreats from Its 'Totality of the Circumstances' Approach to Premises Liability, 28 GA. L. REV. 1053, 1069-70 (1994).

${ }^{50} 36$ Cal. 4th 224, 113 P.3d 1159, 30 Cal. Rptr. 3d 145 (2005). 
Sharon $P$. and appears to return more to the ad-hoc approach of Isaacs. ${ }^{51}$

While there were some disputes about the facts in Delgado, the court based its decision on these essential facts: Michael Delgado and his wife went to Trax Bar and Grill for an evening out. Jacob Joseph, who was with three friends, started staring at Delgado and tensions rose. ${ }^{52}$ Trax's bouncer figured it was easier to ask a single couple to leave than Joseph's group and he asked Delgado to leave. ${ }^{53}$ Delgado agreed and went with his wife into the parking lot. Jacob Joseph followed, gave a signal to $12-15$ of his gang buddies who were outside, and then chased down and brutally beat Michael Delgado. ${ }^{54}$ Delgado spent 16 days in the hospital. ${ }^{55}$ Joseph pled no contest to felony assault and went to prison. ${ }^{56}$

On the appeal of Delgado's negligence claim against the bar based on theories of

${ }^{51}$ The California Supreme Court granted review in the case presumably because the appellate courts had split on the question of whether a property owner who has hired security guards to patrol the premises and protect patrons from harm has assumed a duty to protect patrons from all manner of third-party violence. Compare Mata v. Mata, $105 \mathrm{Cal}$. App. 4th 1121, 130 Cal. Rptr. 2d 141 (2003) (property owner liable for the guard's unreasonable behavior, even in the absence of evidence of prior similar criminal conduct), and Trujillo v. G.A.

Enterprises, Inc., 36 Cal. App. 4th 1105, 43 Cal. Rptr. 2 d 36 (1995) (same), with Nicole M. v. Sears, Roebuck \& Co., 76 Cal. App. 4th 1238, 90 Cal. Rptr. 2d 922 (1999) (no foreseeability and thus no duty where no evidence of similar criminal acts preceding the sexual assault on plaintiff), Hassoon v. Shamieh, 89 Cal. App. 4th 1191, 107 Cal. Rptr. 2d 658 (2001), rev. denied (failure to point to a material factual dispute regarding prior similar incidents of violence at defendants' grocery means the shooting was not foreseeable), and the Delgado appellate court decision, 134 Cal. Rptr. 2d 548 (2003).

${ }^{52}$ See Delgado, 36 Cal. 4th at 230-31, 30 Cal. Rptr. 3d 149.

${ }^{53}$ Id. at 231, 30 Cal. Rptr. 3d at 149. The parties disputed whether Mrs. Delgado informed the bouncer that she feared a fight was about to occur. Id. at 231, n.2, 30 Cal. Rptr. 3d at 149, n.2.

\footnotetext{
${ }^{54}$ Id.

${ }^{55}$ Id. at 232, 30 Cal. Rptr. 3d at 150.

${ }^{56} \mathrm{Id}$.
} 
premises liability, Trax argued that because there was no evidence of prior similar criminal assaults either on its premises or in the vicinity, the assault upon plaintiff was unforeseeable as a matter of law, and that therefore it owed no duty to provide a security guard and could not be held liable for Delgado's injuries. ${ }^{57}$ In return, Delgado argued that defendant owed him a duty of care "because of the special relationship created by the hiring of security guards," and that Trax had a duty to protect him once his wife gave Trax notice of the "potential problem prior to its occurrence., 58

The Delgado court reviewed the Ann M. and Sharon P. decisions, construing them to address only the narrow issue of whether a property owner has a duty to provide security guards. ${ }^{59}$ But, the court continued,

A proprietor that has no duty under Ann M. and Sharon $P$. to hire a security guard or to undertake other similarly burdensome preventative measures still owes a duty of due care to a patron or invitee by virtue of the special relationship, and there are circumstances (apart from the failure to provide a security guard or undertake other similarly burdensome preventative measures) that may give rise to liability based upon the proprietor's special relationship. ${ }^{60}$

The court specifically rejected the argument that a showing of heightened foreseeability always is required when a plaintiff seeks to impose special-relationship-based liability upon a proprietor

${ }^{57}$ Id. at 233, 30 Cal. Rptr. 3d at 151.

${ }^{58} \mathrm{Id}$.

59،"[O]nly when 'heightened' foreseeability of third party criminal activity on the premises exists - shown by prior similar incidents or other indications of a reasonably foreseeable risk of violent criminal assaults in that location - does the scope of a business proprietor's special-relationship-based duty include an obligation to provide guards to protect the safety of patrons." Delgado, 36 Cal. 4th at 240, 30 Cal. Rptr. 3d at 157, citing Ann M., 6 Cal. 4th at 679 \& n. 7, 25 Cal. Rptr. 2d 137, 863 P.2d 207; Sharon P., 21 Cal.4th at 1190-91, 119798, 91 Cal. Rptr. 2d 35, 989 P.2d 121.

${ }^{60}$ Delgado, 36 Cal. 4th at 240-41, 30 Cal. Rptr. 3d at 157. 
related to the criminal conduct of a third party. Instead, purporting to harmonize Isaacs and Ann $M$., the court expressly reaffirmed the "sliding scale balancing formula" approach, which it said it had been using all along. ${ }^{61}$ The court set forth the "guiding principles" as follows:

In circumstances in which the burden of preventing future harm caused by third party criminal conduct is great or onerous (as when a plaintiff, such as in Ann M., asserts the defendant had a legal duty to provide guards or undertake equally onerous measures, or as when a plaintiff, such as in Sharon P. or Wiener, asserts the defendant had a legal duty to provide bright lighting, activate and monitor security cameras, provide periodic "walk-throughs" by existing personnel, or provide stronger fencing), heightened foreseeability - shown by prior similar criminal incidents or other indications of a reasonably foreseeable risk of violent criminal assaults in that location - will be required. By contrast, in cases in which harm can be prevented by simple means or by imposing merely minimal burdens, only "regular" reasonable foreseeability as opposed to heightened foreseeability is required. ${ }^{62}$

The court concluded that Delgado had failed to establish sufficient evidence of prior similar incidents to invoke the heightened foreseeability requirement of hiring more security guards. ${ }^{63}$ But while Trax did not have a duty based on the special relationship to its patron, the court held that Trax did have a duty to respond as events unfolded. ${ }^{64}$ Specifically, the court held

${ }^{61}$ Id. at 243, $30 \mathrm{Cal}$. Rptr. 3d at 160. As a result, the court expressly disapproved Hassoon v. Shamieh, 89 Cal. App. 4th 1191, 1195, 107 Cal. Rptr. 2d 658, which had held that a showing of heightened foreseeability is required in all premises liability cases. Delgado, 36 Cal. 4 th at 244, 30 Cal. Rptr. 3d at 160.

${ }^{62}$ Id. at 243 n.24, 30 Cal. Rptr. 3d at 160 n.24.

${ }^{63}$ Id. at 245, 30 Cal. Rptr. 3d at 161. See also id. at 255, 30 Cal. Rptr. 3d at 165. (Kennard J., dissenting) ("Although in the past there had been some altercations between patrons, none involved gang fights or gang attacks on patrons.”).

${ }^{64}$ Id. at 245, 30 Cal. Rptr. 3d at 161 ("the absence of heightened foreseeability in this case merely signifies that defendant owed no special-relationship-based duty to provide guards or undertake other similarly burdensome preventative measures; it does not signify that defendant owed no other special-relationship-based duty to plaintiff, such as a duty to respond to events unfolding in its presence by undertaking reasonable, relatively simple, and minimally burdensome measures."). 
that Trax had a duty to attempt to prevent Joseph from following Delgado into the parking lot. ${ }^{65}$

Justice Kennard, in dissent, reproved the majority for improperly combining the duty and causation elements of a negligence claim.

[I]nstead of focusing on whether what occurred at the restaurant was foreseeable, the majority decides that here the owner owed a duty to plaintiff because the owner's employee (the security guard) could have done something different that might have broken the causal chain of events. "While causation is an indispensable element of negligence liability, it is neither the only element, nor a substitute for "duty."' Because there are numerous causes of any event that precede its occurrence, it is always possible to point to something that could have been done differently, and the majority's approach is perilously close to imposing liability that has no limits. ${ }^{66}$

Contrary to the majority's approach, Justice Kennard would hold that "the existence and scope of a business owner's duty to protect against a threat of future criminal activity, imminent or otherwise, depends on the foreseeability of the sort of criminal conduct that actually occurred., 67

In Getson v. Edifice Lounge, Inc. ${ }^{68}$ two customers of a bar were stabbed in the bar parking lot by members of a motorcycle gang. The court found no evidence the bar owner or his employees had ever seen the biker who did the stabbing or the other members of the biker gang cause trouble prior to the night of the fight. ${ }^{69}$ When consider the bar owner's duty to protect

${ }^{65}$ Id. at 246 n. 26, 30 Cal. Rptr. 3d at 162 n.26. The "minimally burdensome" measures the court found Trax had a duty to make may have included requiring the bouncer to maintain the separation between Delgado and Joseph's group; having the bouncer engage Joseph's group to dissuade them from following Delgado; confirming that the bouncer stationed in the parking lot was available to maintain the separation between Joseph's group and Delgado. Id. at 246-47, 30 Cal. Rptr. 3d at 162.

${ }^{66}$ Id. at 256, 30 Cal. Rptr. 3d at 170 (Kennard, J., dissenting).

${ }^{67}$ Id. at 256, 30 Cal. Rptr. 3d at 170-71 (Kennard, J., dissenting).

${ }^{68} 117$ Ill. App. 3d 707, 72 Ill. Dec. 826, 453 N.E.2d 131, 135 (Ill. App. Ct.1983).

${ }^{69}$ Id. at 712, 453 N.E.2d at 135, 72 Ill. Dec. at 830 (noting rather disingenuously that "We cannot say as a matter of law that someone who is a member of a motorcycle group and who 
against future criminal acts against customers, the court required firm evidence of the bar owner's knowledge of the biker's actions which would have compelled a reasonably prudent person to conclude that the biker was likely to endanger a customer.

The court then shifted its analysis once the actual criminal assault described in the complaint commenced. The court found that the bar owner clearly knew that the biker was dangerous at that point. ${ }^{70}$ In deciding whether the bar owner acted reasonably when the assault was ongoing, the court acknowledged that the fight lasted between 30 and 45 seconds. ${ }^{71}$ During that time, the bar owner barred the entrance and phoned the police, who appeared nearly instantaneously. ${ }^{72}$ Under the circumstances, the court found that the bar owner acted reasonably and therefore was not negligent. ${ }^{73}$

By contrast, the California approach may well lead to unintended consequences. The Delgado majority held that because the bar owner knew a criminal act was imminent (which was why he asked Delgado to leave), then the bar owner had a responsibility to attempt to prevent the thug who initiated the attack from following Delgado out into the parking lot. Yet the creation of a duty under that circumstance presents the potential for a very cautious bar owner to restrain a potentially violent patron only to be served with a lawsuit claiming false imprisonment. "“The

happens to carry a buck knife is per se dangerous" and further finding no evidence that the particular biker in this case was "a troublemaker.").

${ }^{70}$ Id. at 713,453 N.E.2d at 135,72 Ill. Dec. at 830.

${ }^{71}$ Id.

${ }^{72} \mathrm{Id}$.

${ }^{73}$ Id. However, it does appear that the key point for the court was that, given all the efforts made by the bar owner to protect his customers, the stabbing still occurred. Therefore, it would appear that the plaintiff's claim falters on causation, not duty. 
tort of false imprisonment is the nonconsensual, intentional confinement of a person, without lawful privilege, for an appreciable length of time....' A person is falsely imprisoned 'if he is wrongfully deprived of his freedom to leave a particular place by the conduct of another.,"74 Restaurants have been held liable for false imprisonment of patrons. ${ }^{75}$ Thus, the Illinois court's approach takes a more realistic view of the ability of a business owner's employees to react and the manner in which the y are likely to react - to a sudden crime in progress.

\section{II.}

\section{TWISTS IN THE TALE}

Most premises liability cases follow some general patterns. Common scenarios include: (1) where a business's patron is attacked in a secluded areas of the premises, particularly the parking lot or parking garage or abducted from the parking lot or garage and injured or killed off the premises; ${ }^{76}$ (2) incidents of domestic violence where an enraged boyfriend or estranged husband gains entry to an apartment and injures his former girlfriend or wife, ${ }^{77}$ and (3) innocent

\footnotetext{
${ }^{74}$ Hagberg v. California Federal Bank FSB, 32 Cal. 4th 350, 372-73, 7 Cal. Rptr. 3d 803, 819 (2004) (citations omitted); see e.g., Cal. Penal Code $\S 236$; Blaxland v. Commonwealth Director of Public Prosecutions, 323 F.3d 1198, 1205 (9th Cir. 2003) (under California law, the elements of false imprisonment are (1) the nonconsensual, intentional confinement of a person, (2) without lawful privilege, and (3) for an appreciable period of time, however brief).

${ }^{75}$ See e.g., Stroud v. Denny’s Restaurant, Inc., 271 Or. 430, 431, 532 P.2d 790, 791 (Or. 1975) (customer detained for failure to pay for toast that was topped with a refrigerated butter pat rather than the melted butter pictured in the menu was awarded \$1,000 in compensatory damages and \$9,000 in punitive damages); Keys v. Sambo's Restaurant, Inc., 398 So.2d 1083, 1085 (La., 1981) (restaurant detained customer for failure to pay, which escalated when the customer hit a restaurant employee, who, fearing harm to other customers and restaurant employees, then locked the customer in a bathroom stall and called police).
}

${ }^{76}$ See e.g., Maheshwari v. City of New York, 2 N.Y.3d 299, 810 N.E.2d 894, 778 N.Y.S.2d 442 (2004); McClung v. Delta Square Ltd. Partnership, 937 S.W.2d 891, 902 (Tenn. 1996); Doe v. Wal-Mart Stores, Inc., 198 W. Va. 100, 479 S.E.2d 610 (1996).

${ }^{77}$ See e.g., Vasquez v. Residential Investments Inc., 12 Cal. Rptr. 3d 846, 118 Cal. App. 
people at a gathering (e.g., at a movie theater or concert) who are injured when part of the crowd turns ugly. ${ }^{78}$ But some of the cases present facts that one would think could exist only in the minds of fiendish tort professors developing final examination questions. Wary of the admonition that bad facts make bad law, ${ }^{79}$ courts have had to grapple with some very difficult cases which present twists on the generally straightforward fact patterns just described. Three of these twists in the tale are presented below.

\section{A. Twist \#1: The "Tragically Bizarre" Event Leading to Injury}

Because the "tragically bizarre" premises liability case must be a rarity by definition, there are few cases that have addressed this situation. However, freak accidents and astonishingly horrid intentional acts do occur and the question remains whether the purposes of tort law are furthered by finding a property owner liable on a premises liability theory for these incidents. A defendant's negligence liability is, however, limited by rules designed to cut off what might otherwise become an unbearable responsibility to ensure against every possible risk. ${ }^{80}$ Property owners could imagine an endless number of potential dangers to customers or persons on their property. But negligence law does not require them to take precautions against

4th 269 (Cal. Ct. App. 2004). Cf. Monk v. Temple George Associates, LLC, 273 Conn. 108, 869 A.2d 179 (Conn. 2005) (domestic violence type crime occurring in a parking lot).

${ }^{78}$ See e.g., The New Addition Club, Inc. v. Vaughn, 903 So.2d 68 (Ala. 2004)

${ }^{79}$ See Doggett v. United States, 505 U.S. 647, 659, 112 S.Ct. 2686, 2694, 120 L.Ed.2d 520 (1992) (Thomas, J., dissenting) (further noting a corollary that "odd facts make odd law.”).

${ }^{80}$ See Harvey S. Perlman, Interference with Contract and Other Economic Expectancies: A Clash of Tort and Contract Doctrine, 49 U. CHI. L. Rev. 61, 70 (1982) ("The consequences of any act can be traced indefinitely, but tort law has never made a defendant pay for all harm caused by his tortious act, however remote. At some point, it is generally agreed that the defendant's act cannot fairly be singled out from the multitude of other events that combine to cause loss."). 
every risk - only to take reasonable precautions against foreseeablerisks. These terms protect the property owner from having to take irrational precautions against freakish risks. ${ }^{81}$ Tort law should impose a duty only to take reasonable precautions - not precautions against risks that are so unlikely to occur that, although perhaps logically foreseeable, are not worth guarding against because doing so would impose too high a social cost. ${ }^{82}$

Most jurisdictions decline to extend a duty to landowners confronted with "tragically bizarre" criminal acts. For example, Illinois courts have held that "[t]he creation of a legal duty requires more than a mere possibility of occurrence. .. 'No [one] can be expected to guard against harm from events which are not reasonably to be anticipated at all, or are so unlikely to occur that the risk, although recognizable, would commonly be disregarded."” 83 In other words, "[a]n occurrence is reasonably foreseeable if a reasonably prudent person could have foreseen as likely the events which did transpire. If those events are 'highly extraordinary' or 'tragically

\footnotetext{
${ }^{81}$ See United States v. Carroll Towing Co., 159 F.2d 169, 173 (2d Cir. 1947) (stating Judge Learned Hand's famous economic formula):

if the probability [of the harm] be called P; the [gravity of the] injury, L; and the burden [of Defendant taking precautions], B; liability depends upon whether B is less than L multiplied by P: i.e., whether B $<$ PL.

${ }^{82}$ See Kolodziejzak v. Melvin Simon \& Associates, 292 Ill. App. 3d 490, 498, 226 Ill.Dec. 530, 536 (Ill. App. 1997) ("How many guards would [a shopping center management company] have to hire to protect against any criminal act occurring in the common area of a shopping center which is open to the public? 2? 50? or 100? Alternatively, what else could [the management company] do except erect a fence around Yards Plaza and screen all persons entering the premises? Either of these scenarios would certainly place too onerous an economic burden on [the management company].”)

${ }^{83}$ Cunis v. Brennan, 56 Ill.2d 372, 375-76, 308 N.E.2d 617, 619 (Ill. 1974) (quoting W. Prosser, Handbook of the Law of Torts § 31, at 146 (4th ed. 1971)). See also Rex A. Sharp, Paying for the Crimes of Others? Landowner Liability for Crimes on the Premises, 29 So. TEX. L. REV. 11, 17-18, n.16 (1987) ("Why not single out the criminal's parents for not teaching him to obey the law; the schools for not teaching him a trade; the city for permitting degrading slum areas that breed crime; the police for not preventing crime; the courts for not locking him up and keeping him from hurting others, or the prisons for not rehabilitating him?").
} 
bizarre' or 'unique' then the occurrence is not reasonably foreseeable." ${ }^{\text {84 }}$ Montana law similarly holds that foreseeability analysis cuts off a defendant's liability from consequences that are "freakish, bizarre or unpredictable." 85

In Wiener v. Southcoast Childcare Centers, Inc. ${ }^{86}$ the California Supreme Court applied these principles in a case arising from a tragedy. Steven Abrams, seeking to "execute innocents," deliberately accelerated his Cadillac over a curb, across a sidewalk, and through a four foot high chain link fence onto a preschool playground, mowing down several children and killing Brandon Wiener and Sierra Soto. He was tried and convicted for the murders, and sentenced to life in prison without the possibility of parole. ${ }^{87}$

Brandon's and Sierra's parents sued the preschool operator, Southcoast Child Care Centers, as well as the First Baptist Church that leased the property to Southcoast for negligence and premises liability. ${ }^{88}$ They alleged that the defendants were negligent by their failure to provide a more significant barrier between the street and the playground or by their failure to

${ }^{84}$ Zakoff v. Chicago Transit Authority, 336 Ill. App. 3d 415, 422, 270 Ill. Dec. 314, 320 782 N.E.2d 873, 879 (Ill. 2002) (quoting Michalak v. County of LaSalle, 459 N.E.2d 1131, 1132 (Ill. 1984)).

${ }^{85}$ Sizemore v. Montana Power Co., 246 Mont. 37, 46, 803 P.2d 629, 635 (Mont. 1990). See also Aguillard v. Langlois, 471 So.2d 1011, 1014 (La. App. 1985) (Plaintiff sued when he was struck by a pecan hurled 45 feet by a bushhog mowing a large tract of land. The court, referring to the incident as a "freak accident," held that "the small magnitude of the risk of injury from being struck in the eye by an object thrown 45 feet from a bushhog is outweighed by the onerous burden we would place upon landowners by requiring them to bushhog only when no one else was present on the land, or requiring them to scour every square inch of the land to be bushhogged in order to discover potential projectiles.").

${ }^{86} 32$ Cal. 4th 1138, 88 P.3d 517, 12 Cal. Rptr. 3d 615 (2004).

${ }^{87}$ Id. at 1143, 12 Cal. Rptr. 3d at 618.

${ }^{88} \mathrm{Id}$. 
locate the playground on a part of the property away from the street. ${ }^{89}$ A Southcoast employee had requested funds from the Church to reinforce the fence, but the request was denied. (The reason for the request was not related to traffic, however; she was concerned about the risk of children climbing over the existing fence) ${ }^{90}$

The trial court granted summary judgment to the defendants, finding that they could not have foreseen Abrams' criminal conduct and, consequently, had no duty to protect against it. ${ }^{91}$ In a 2-1 split, however, the Court of Appeal reversed. In reaching its decision, the majority used a balancing test to determine the foreseeability of the potential harm to determine the scope of Southcoast's duty to protect. Although Abrams' intentional criminal act of driving his car into the playground might not be a foreseeable harm, the possibility of an automobile unintentionally veering into the playground was foreseeable, the court concluded. This was the "kind of harm" for which liability can be imposed, the court noted. ${ }^{92}$

Applying similar reasoning, the court rejected the defendants' argument that Abrams' intentional criminal act was a superseding cause that broke the chain of causation between the defendants' negligence and the death of the children. Because the hazard of a car hitting the day care center's fence was reasonably likely, the court held that Southcoast could be held liable for the resulting harm regardless of whether the act was negligent, innocent or criminal. ${ }^{93}$

${ }^{89}$ Id. at 1144,12 Cal. Rptr. 3d at 618.

${ }^{90}$ See id. at 1145,12 Cal. Rptr. 3d at 619.

${ }^{91}$ Id. at 1145, 12 Cal. Rptr. 3d at 619-20.

${ }^{92}$ Id. at 1145, 12 Cal. Rptr. 3d at 620. See also Wiener v. Southcoast Childcare Centers, Inc., 132 Cal. Rptr. 2d 883, 03 Cal. Daily Op. Serv. 3384, 2003 Daily Journal D.A.R. 4295 (Cal.App. 4 Dist. Apr 22, 2003).

${ }^{93}$ Wiener, 132 Cal. Rptr. 2d at 888. 
The dissent opined that the nature of the risk, not a generic kind of harm, defines the duty owed. As examples, the dissent cites the "difference in risk between a stray bullet from a firing range and a gunshot fired with intent to kill, between accidentally poking someone next to you with a pencil and stabbing them with it, between accidentally hitting a pedestrian because you lose control of a car and trying to use the car as a deadly weapon by mowing someone down."94

The California Supreme Court granted the preschool's petition for review. The question before the California Supreme Court was "Under what circumstances may the operators of a preschool be held liable for injuries incurred by the preschool's students when a third-party assailant drove his car through a four-foot high chain link fence and onto the preschool's playground?"95 The state high court reversed the appellate decision.

One point of controversy was how to consider a previous accident, in which an unmanned mailtruck rolled through the fence and onto the schoolyard, coming to rest against a tree without causing any injuries. The court described this incident, which it described as a "freak accident.",96

According to a neighbor, a mail truck pulled up to the sidewalk across the street from the child care center, and the mail carrier reached out of his truck to open the adjacent mailbox. As the mail carrier reached for the box, he slipped, did a flip, and landed between the mailbox and the truck. The truck took off and headed toward the fence across the street. At the time, the property was leased by another school, not Southcoast. The truck bounced over the curb and went through the

\footnotetext{
${ }^{94}$ Id. at 894 (Sills, J., dissenting).

${ }^{95}$ Petition for Review, on file with author.

${ }^{96} 32$ Cal. 4th at 1143, 88 P.3d at 521, 12 Cal. Rptr. 3d at 618.
} 
fence before coming to a stop at a tree inside the yard. Other than the mail

carrier, who hurt his back, no one was injured in the incident. ${ }^{97}$

The question was whether this incident led to the foreseeability of Abrams' acts. The court of appeal viewed this accident as one of "errant traffic" breaching the fence and thus found that any future incident of a vehicle breaching the fence must be foreseeable.

The California Supreme Court rejected this approach and held that a vehicle driven with criminal intent to kill is different in kind than a runaway mailtruck or even a negligently driven automobile which jumps the curb. The court chastised the Court of Appeal for failing to "give due consideration to the criminal nature of Abrams's injury-producing act, and thus created a duty test that is far too broad, even when we are dealing with the landowner's duty to protect children from perils that reasonably could have been foreseen." ${ }^{, 98}$ The court distinguished "ordinary negligence action[s]," in which "the precise details of the third party's actions are not overly significant." ${ }^{\text {99 }}$ Relying on Ann M.'s requirement of heightened foreseeability, the court distinguished third party criminal acts from ordinary negligence. The court cited two policy reasons for its conclusion: "first, it is difficult if not impossible in today's society to predict when a criminal might strike. Also, if a criminal decides on a particular goal or victim, it is extremely difficult to remove his every means for achieving that goal."100

${ }^{97} \mathrm{Id}$.

${ }^{98}$ Id. at 1149,88 P.3d at 524, 12 Cal. Rptr. 3d at 623.

${ }^{99}$ Id. citing Robison, 64 Cal. App. 4th 1294, 1298, 75 Cal. Rptr. 2d 838 (1998).

${ }^{100}$ Id. This was consistent with the decision in Robison, which made the distinction between acts of ordinary negligence and criminal acts by noting that "[ $\mathrm{t}]$ he burden of requiring a landlord to protect against crime everywhere has been considered too great in comparison with the foreseeability of crime occurring at a particular location to justify imposing an omnibus duty on landowners to control crime." The court concluded that "[ $t]$ here is no legal requirement in 
Applying Ann M., the supreme court concluded that the preschool owed no duty to the

plaintiffs because Abrams's horrific, criminal act was unforeseeable. ${ }^{101}$

No evidence indicated defendants' child care facility had ever been the target of violence in the past and no hint existed that either defendants or any other similar business establishment had ever been the target of any criminal acts. Indeed, here, the foreseeability of a perpetrator's committing premeditated murder against the children was impossible to anticipate, and the particular criminal conduct so outrageous and bizarre, that it could not have been anticipated under any circumstances. $^{102}$

[circumstances surrounding a foreseeable accident] for the type of heightened notice which might be provided by a prior similar incident, as Ann $M$. found may be necessary in instances of third party crime." Id.

${ }^{101}$ Id. at 1150, 88 P.3d at 525, 12 Cal. Rptr. 3d at 624 citing Ann M., 6 Cal.4th at 676-679, 25 Cal. Rptr. 2d 137, 863 P.2d 207.

${ }^{102} \mathrm{Id}$. One might argue that the first mail truck incident drew a circle of foreseeable second incidents of cars breaching the fence; cars breaching the fence due to criminal intent of drivers is logically within that circle. So the argument that the criminal nature of the second incident removes it from that circle (i.e., makes it unforeseeable) is not really a dispute about foreseeability at all, but a request for an exception to the duty of reasonable care to which the first incident gave rise. Justice Moreno seemed amenable to this approach in his concurring opinion: "[i]f an automobile enters the playground and injures a child and the driver is killed, it may be difficult to determine whether the driver acted intentionally or negligently." Wiener, 30 Cal. 4th at 1152, 12 Cal. Rptr. 3d at 625 (Moreno, J., concurring). Adopting a rule which "hinges...upon the mental state of a third party that causes injury, rather than upon whether the landowner was negligent in failing to guard against the type of danger," would leave courts no guidance in deciding such a case. Id. (Moreno, J., concurring).

If one were to granting that the mail truck incident made a second breaching of the fence foreseeable, the landowner would still not be liable because no reasonably affordable fence could have repelled Abrams' intentional attack-or an intentional attack launched by a heavier vehicle, like a Ford Explorer. The California Supreme Court acknowledged this, emphasizing the " $\mathrm{t}] \mathrm{he}$ burden of requiring a landlord to protect against crime," and the importance of "balanc[ing] the foreseeability of the criminal act against the burden, vagueness, and efficacjof the proposed security precaution." Id. at 1147, 12 Cal. Rptr. $3 \mathrm{~d}$ at 621 . The court might have avoided this confusion by phrasing the question not as whether the daycare center owed a duty to prevent wayward cars from entering the property by erecting a stronger fence, but whether its failure to do so was the proximate cause of the harm to the children. Because no reasonably affordable fence could have done so - indeed, the Court found that nothing short of a "fortress" could have done so (id. at 1151, 12 Cal. Rptr. at 624) - then the breach of the duty was not the proximate cause of the children's deaths. The author is grateful to Timothy Sandefur for suggesting this analysis. 
Another tragically bizarre case arose in South Dakota. Mary K. Ross lived in an apartment with her infant daughter. Her friend Amy Power was having marital difficulties and Ms. Ross invited her to move in and provided her with an apartment key. On one occasion, she also gave a key to Mrs. Power's husband, Robert, asking him to make a copy for Ms. Ross's babysitter. Amy Power later lost her copy of the key. As the Powers' marriage disintegrated, Robert Power blamed Ms. Ross and sought revenge. He engaged in a conspiracy to murder her, hiring two assassins to do the job and providing them with a copy of Ms. Ross's apartment key. The hired killers let themselves into Ms. Ross's apartment one night and stabbed her to death. Robert Power and the other conspirators were convicted and given life sentences. ${ }^{103}$

Ms. Ross's mother, Sherry K. Smith, sued the owners of the apartment complex for failing to replace the lock. In a 3-2 split decision, the South Dakota Supreme Court found the complex liable because the owners had sole responsibility for changing the locks and failed and to do so and because the court found that it was foreseeable that a lost key could result in unauthorized access and criminal behavior. The dissent disagreed on two grounds. First, the apartment owner did not have exclusive control over the locks because Ms. Ross herself shared the key with Amy Power, and, five months before her murder, to Robert Power himself. Second, the dissent found that the contract killing that occurred in this case could not have been the foreseeable result of the apartment owner's failure to promptly replace the lock. This makes complete sense. Mary Ross herself obviously never considered that Robert Power would contract to have her killed - she voluntarily gave him her apartment door key. The apartment

${ }^{103}$ Shannon E. Kelly, South Dakota Supreme Court Opens the Door to Landlord Liability for Criminal Attacks Committed by Third Parties on the Premises: Smith v. Lagow Construction \& Developing Company, 48 S.D. LAW REV. 365, 369 n.56 (2002-03). 
owner should not be held to a higher standard of foreseeability. ${ }^{104}$

The court's reaction to this tragic case dramatically expands landowner liability in the state. If one of the purposes of tort law is to fashion rules to deter particular injuries from occurring, ${ }^{105}$ the expansion of liability in this case is unlikely to reduce the number of contract killings in South Dakota (which, presumably, are very few). Instead, it will invite future litigation that pushes landowners ever closer to being insurers of the public safety.

Professor William Jones provides a useful analysis in which he refines the distinction between intentional and negligent behavior ${ }^{106}$ by looking at a subset of intentional acts that are defined as predatory or nonpredatory behavior. ${ }^{107}$ Predatory behavior is marked by these features: It

has [no] redeeming social value; society would be better off if all such behavior simply ceased. Second, the threat posed by these practices compels persons to incur costs, financial and personal, to avoid being victimized; to install locks and bolts, to be wary about admitting strangers onto the premises, to limit one's freedom of action so as to avoid dangerous areas at dangerous times, and so forth. In effect, the predator imposes on other members of society costs that are socially wasteful and would be wholly unnecessary in the absence of predation. ${ }^{108}$

${ }^{104}$ Id. at 386 n. 261.

${ }^{105}$ See generally Gary T. Schwartz, Mixed Theories of Tort Law: Affirming Both Deterrence and Corrective Justice, 75 TEX. L. REV. 1801(1997).

106،[I]ntentional torts are of a fundamentally different nature than negligent torts, ... [and] a true comparison of fault . . . is, in many circumstances, not possible. . . . [I] n such a comparison, how can a rapist . . . not be $100 \%$ liable for his actions?' The common sense answer [is] that intentional wrongdoing 'differs from negligence not only in degree but in kind." Veazey v. Elmwood Plantation Assocs., Ltd., 650 So. 2d 712, 719-20 and n.11 (La. 1994) (citation omitted).

${ }^{107}$ William K. Jones, Tort Triad: Slumbering Sentinels, Vicious Assailants, and Victims Variously Vigilant, 30 HOFSTRA L. REV. 253, 263 (2001).

${ }^{108}$ Id. at $263-64$. 
This analysis suggests that there is a continuum of decreasing morally culpable actions that runs from intentionally predatory to intentionally nonpredatory to negligent. Where an action falls on this continuum impacts the level of foreseeability. This is the difference between an automobile intentionally used to murder people and "errant traffic" that might accidentally result in harm.

This predatory/nonpredatory distinction is supported in the holding in Hillcrest Foods, Inc. v. Kiritsy, ${ }^{109}$ in which the Georgia Court of Appeal held that a Waffle House restaurant (owned by Hillcrest) could not be held liable when an innocent patron (Kiritsy) was injured by a waitress's estranged husband in a drive-by shooting that was aimed at her. The court held:

[Hillcrest] cannot be responsible for Kiritsy's injuries because the drive-by shooting was not a foreseeable act. It was an act of terrorism that could have occurred anywhere that the intended victim happened to be. Hillcrest had no basis to foresee such event, and there was no effective action which it could reasonably have taken to prevent said act under the circumstances of this case. Hillcrest and Kiritsy are both victims of the despicable shooting for the same reason. That being the perpetrator's decision to shoot Letitia Johnson at the subject time and location. The shooting was a transitory act that could have been carried out at any time and place that the intended victim happened to be. ${ }^{110}$

A similar situation was present in Glick v. Prince Italian Foods of Saugus, Inc., ${ }^{111}$ in which restaurant patrons sued the restaurant owner for personal injuries sustained when an automobile crashed through the exterior wall of the restaurant. The court held that the owner "had no obligation or duty to construct an impenetrable barrier surrounding its restaurant to prevent errant automobiles from entering the building as it is not reasonably foreseeable that such an incident will occur, resulting in such injuries as the plaintiffs suffered." ${ }^{112}$ The court relied on a

\footnotetext{
${ }^{109} 227$ Ga. App. 554, 558-59, 489 S.E.2d 547, 551 (Ga. App. 1997).

${ }^{110} \mathrm{Id}$.

${ }^{111} 25$ Mass. App. Ct. 901, 901-02, 514 N.E.2d 100, 101 (Mass. App. Ct. 1987).

${ }^{112} \mathrm{Id}$.
} 
Florida case, Schatz v. 7-Eleven, Inc. ${ }^{113}$ which held that

[it is an] obvious fact that at times operators lose control over the forward progress and direction of their vehicles .... In a sense all such occurrences are foreseeable. They are not, however, incidents to ordinary operation of vehicles, and do not happen in the ordinary and normal course of events.... [T]he consequences resulting therefrom are matters of chance and speculation. If ... such occurrences are held to be foreseeable and therefore to be guarded against, there would be no limitation on the duty owed by the owners of establishments into which people are invited to enter.

The Massachusetts court thus concluded that a defendant will not be held liable "for all possible injury no matter how remote or farfetched. The cause of the injury must be reasonably foreseeable. There is no duty owed when the risk which results in the plaintiff's injury is not one which could be reasonably anticipated by the defendant." ${ }^{114}$

The tragically bizarre cases, which seem to feature assailants driven by a deep desire to do harm or kill, demonstrate that courts' view that, at some level of heinousness, a criminal act causing great harm will be deemed less foreseeable than a less serious criminal act of the same variety. For example, if Steven Abrams had merely lost control of his car, careened into the preschool playground, and injured or killed some children, it is likely that the court would have viewed the earlier mail truck incident as a foreshadowing event that could have resulted in liability for the landowner. The court's focus on Abrams' homicidal intent placed the analysis outside the realm of the more typical foreseeability analysis.

\section{B. Twist \#2: Tenant-on-Tenant Crime}

1. Courts Distinguish Between Crimes Committed by Intruders and by Those Authorized To Be on the Premises

Landowners may be liable for failure to maintain minimal security measures in the face

${ }^{113} 128$ So. 2d 901, 904 (Fla. App. 1961).

${ }^{114}$ Glick, 514 N.E.2d at 102. 
of foreseeable criminal intrusion upon tenants. A key element to these cases often is the plaintiff's ability to prove that the assailant was, in fact, an intruder rather than someone authorized to be on the presmises. This usually comes up in the foreseeability aspect of causation - the theory being that no amount of security to keep people out will prevent an attack by someone authorized to be in. ${ }^{115}$ But sometimes it arises in the context of duty as well. ${ }^{116}$

Courts in many jurisdictions demand evidence that the perpetrator was not or could not have been lawfully on the premises as a necessary condition to finding liability. ${ }^{117}$ In Morton v. Kirkland, ${ }^{118}$ the plaintiff sued her landlord when another tenant assaulted her on the grounds that the landlord knew of the tenant's propensities and failed to evict him. The District of Columbia

${ }^{115}$ See Western Investments, Inc. v. Urena, 162 S.W.3d 547, 550 (Tex. 2005) (finding that even if the court assumed a duty existed, the plaintiff failed to establish that the existence of any of the security measures demanded would have prevented the assault that formed the grounds of the complaint).

${ }^{116}$ See Rogers v. Jones, 56 Cal. App. 3d 346, 352, 128 Cal. Rptr. 404, 408 (1976), in which the court declined to impose a duty on a football stadium parking lot operator to prevent an attack by one fan on another. The court held that the measures needed to prevent that incident would be unreasonably burdensome, necessitating one guard be provided for every fan, and concluding the harm to the plaintiff was not sufficiently foreseeable to warrant that heavy burden. Id.

${ }^{117}$ See, e.g., Post Props., Inc. v. Doe, 230 Ga. App. 34, 37-38, 495 S.E.2d 573, 577 (Ga. Ct. App. 1997) (denying liability because, although the attacker could have entered because of the defendant's negligence, he also could have been authorized to be on the premises); N.W. v. Amalgamated Trust \& Sav. Bank, 196 Ill. App.3d 1066, 1077, 143 Ill. Dec. 694, 702, 554 N.E.2d 629, 637 (Ill. App. Ct. 1990) (stating that it is a "well settled rule that liability cannot be predicated upon surmise or conjecture as to the cause of the injury"); Perry v. N.Y. City Hous. Auth., 222 A.D.2d 567, 567, 635 N.Y.S.2d 661, 662 (N.Y.A.D. 1995) (holding that, where a building had no locks for the outside doors, the landlord was not liable to a tenant assaulted by her ex-boyfriend because the plaintiff offered no evidence that her assailant took advantage of the unlocked doors or that the assailant was an intruder with no right or privilege to be present there); Lester v. N.Y. City Hous. Auth., 292 A.D.2d 510, 511, 739 N.Y.S.2d 200, 201 (N.Y.A.D. 2002) (the plaintiff could not recover because she failed to demonstrate how the assailant gained entry, or that he was not another tenant's invitee or otherwise permitted to be in the building).

${ }^{118} 558$ A.2d 693 (D.C. 1989). 
Court of Appeals held:

To prevail in an action against the landlord predicated on the criminal acts of a fellow tenant, a complaining tenant must establish both that the criminal conduct was foreseeable and that it would have been prevented if the landlord had acted with reasonable prudence under all of the circumstances.

... . The plaintiff herself testified that she was surprised by Grant's assault, and we find it difficult to discern under these circumstances how the landlord could be expected to anticipate it. ${ }^{119}$

Similarly, in Saelzler v. Advanced Group 400, the California Supreme Court concluded that a Federal Express employee, who was assaulted by three men inside an apartment complex while attempting to deliver a package to a resident, could not show that the apartment owners" "failure to provide increased daytime security at each entrance gate or functioning locked gates was a substantial factor in causing her injuries."120 The plaintiff was unable to identify her assailants and, therefore, it was possible that they could have been either authorized trespassers or tenants of the apartment complex. If the assailants were tenants of the complex, who would have been authorized to enter the premises, any increase in the security would not have prevented the attack. $^{121}$

\section{Duty to Monitor Potential and Existing Tenants Places Landlords in a Catch-22}

If there is a duty on the part of the landlord to protect the tenant against criminal acts perpetrated by a fellow tenant, landlords of both residential and commercial properties may then be found to have a duty to investigate their tenants, both prospectively and continuously during the tenancy, to determine the tenant's propensity for criminal behavior. The landlord would have

\footnotetext{
${ }^{119}$ Id. at 695.

${ }^{120}$ Id. at 1152 .

${ }^{121}$ See id.
} 
to decide whether to screen prospective tenants for criminal propensity, ${ }^{122}$ refuse to rent to such individuals, or evict tenants who are potentially dangerous to other tenants. ${ }^{123}$ If the landlord does take action to protect other tenants, the landlord may face claims from the dangerous tenant who has been subjected to the landlord's protective actions. ${ }^{124}$

In Gill v. N.Y. City Hous. Auth., ${ }^{125}$ the New York intermediate appellate court held that a landlord (in this case, the Housing Authority) has no duty to investigate a tenant's mental

${ }^{122}$ Were landlords to engage in more extensive tenant screening, they would likely hire a fee-based tenant-screening service to investigate aspects of a prospective tenant's life, ranging from whether he has ever been named in an unlawful detainer action to his criminal record, credit record, and employment history. See, e.g., Website of ATS, Inc. Employment and Tenant Screening, http://www.atshome.com/ reports/index.html (visited June 25, 2004) (detailing different levels of reports available for purchase).

${ }^{123}$ Another likely cost of landowner liability for third-party criminal acts is insurance. Because the landowners are sued on theories of negligence rather than for an intentional tort, they should be able to obtain insurance coverage for such lawsuits. This does not come cheap, however. According to one report, the average "settlement[ ] paid by insurance companies on behalf of landlords for crimes like rape and assault in the U.S. is more than $\$ 500,000$ [and $t$ ] he average jury award for cases that actually go to trial is $\$ 1.2$ million." Theresa D. Teare, Don't Buy. . . Rent! Maryland Law Provides Limitless Insurance for Tenants Against Criminal Activity after Hemmings v. Pelham Wood, 34 U. BALT. L. REV. 131, 156 (2004) (citations omitted). Landlords required to maintain insurance that adequately covers the risk of million dollar settlements will pass through the cost of that insurance to the tenants through increased rent. Id. Of course, if the tenants cannot afford the increased rent, they will have to look elsewhere for housing, probably having to settle for an even worse neighborhood that has lower rents. The persons most harmed, then, are those on the lower rungs of the economic ladder. See Jennifer S. Fahey, Landlord Liability in West Virginia for Criminal Acts on the Premises, 98 W. VA. L. REV. 659, 699 (1996) citing Miller v. Whitworth, 193 W.Va. 262, 267-68, 455 S.E.2d 821, 82627 (W. Va. 1995)) (a "shortage of low-income housing would ensue if landlords in high crime areas were burdened with a duty based merely on known criminal activity in the neighborhood.").

${ }^{124}$ Saxer, “Am I My Brother's Keeper?”, 80 Neb. L. Rev. at 561; see also Ray Dozier, A Consultant's View of the Future Real Estate, J. Rec. (Oklahoma City), Aug. 25, 2000, 2000 WL 14297953 (predicting a "flood of privacy and should-have-been-told lawsuits" and predicting that the "sharing, or disclosing, of data on tenants with others will be rigorously fought by lessees").

${ }^{125} 130$ A.D.2d 256, 261, 519 N.Y.S.2d 364, 369 (N.Y.A.D. 1987). 
condition prior to renting him an apartment nor does the landlord have a duty to investigate a tenant's mental condition, treatment, or medication during the course of the tenancy. The court's public policy analysis counseled firmly against liability:

The practical consequences of an affirmance in this case would be devastating. The Housing Authority would be forced to conduct legally offensive and completely unwarranted "follow-ups" of all those tenants within its projects known to have a psychiatric condition possibly, but it must be noted, not foreseeably, injurious to another tenant. Once the "follow-up" had been conducted, the Housing Authority would then be obligated to look into its crystal ball to assess the likelihood of harm and then, where indicated, to take protective measures for which it has no expertise or authority. These would include dispensing medication, monitoring treatment, posting warnings (i.e., "Beware of your neighbor"), or evicting tenants. Given the options, eviction, which is described in the Housing Authority Management Manual as a "last resort," would become almost commonplace. Those with psychiatric disorders would be dispossessed from their low income accommodations to live in the streets. The equally unacceptable alternative would be for the Housing Authority to expose itself to staggering liability. ${ }^{126}$

Potential liability for tenant-on-tenant crime thus places landlords in an unacceptable

legal quandary. If, for example, the landlord knows of a tenant's potentially violent mental illness, but lacks notice of any previous aberrant conduct, the landlord's failure to inform the other residents about the tenant's condition may render the landlord liable for a subsequent violent act perpetrated by the mentally ill tenant if there had indeed been a breach of some duty to warn other tenants of potential violent activity. ${ }^{127}$ Predicting which tenants are likely to

${ }^{126}$ Id. at 266.

${ }^{127}$ See Frederic White, Outing the Madman: Fair Housing for the Mentally Handicapped and Their Right to Privacy Versus the Landlord's Duty to Warn and Protect, 28 FordHAM URB. L.J. 783, 785, 793 (2001) (as a result of disclosure, tenants may choose to vacate their units and warn off other potential tenants from the premises). See also United Prop. Owners Ass'n of Belmar v. Borough of Belmar, 343 N.J.Super. 1, 49, 777 A.2d 950, 979 (N.J. Super. A.D. 2001) (holding that compelled disclosure of personal information about tenants could make it more difficult for owners to find tenants and could decrease the value of rental properties). 
commit future crimes can be a complicated, if not impossible, task. In Williams v. Gorman, ${ }^{128}$ the court held that because the violent tendencies of a tenant who lived upstairs from the victim were not known to the landlord, there was no duty to evict the tenant in advance of a gunshot blast through the victim's ceiling. In De Leon v. Creely, ${ }^{129}$ the court held that annoying but nonviolent misconduct does not show a propensity to commit a violent crime. Likewise, "unusual acts are not a harbinger of dangerous criminal conduct. Suspicious and unusual do not equate to foreseeable danger." 130

It is difficult for landlords to find reliable crime predictors that do not invade the privacy of potential tenants or impermissibly discriminate against them. ${ }^{131}$ Assuming the landlord is held liable for foreseeable criminal acts by one tenant against another for negligently renting to the offending tenant, there will be an issue as to whether the landlord has a continuing duty to check the local police records for information regarding its current tenants. ${ }^{132}$ The landlord may have to regularly question other tenants or review criminal records during the tenant's occupancy to determine whether the tenant had exhibited a criminal propensity that may not have existed at the time of first rental. ${ }^{133}$

${ }^{128} 214$ N.J.Super. 517, 524, 520 A.2d 761, 765 (N.J. Super. Ct. App. Div. 1986).

${ }^{129} 972$ S.W.2d 808, 813 (Tex. App. 1998).

${ }^{130}$ See Gonzalez v. Mobil Oil Corp., 2001 WL $722564 * 4$ (Tex. App. 2001) (not designated for publication).

${ }^{131}$ B.A. Glesner, Landlords as Cops: Tort, Nuisance \& Forfeiture Standards Imposing Liability on Landlords for Crime on the Premises, 42 CASE W. RES. L. REV. 679, 780 (1992).

${ }^{132}$ Saxer, “Am I My Brother's Keeper?”, 80 NEB. L. REV. at 568.

${ }^{133}$ See Glesner, Landlords as Cops, 42 CASE W. RES. L. REV. at 715 (noting that "it is likely that a duty to police tenants will develop further"). Once a tenant has committed a crime, however, the landlord may evict the tenant without further ado. Dep't of Hous. \& Urban Dev. v. 


\section{Tenants Have a Right to Keep Certain Information Private}

One type of privacy interest that is protected by the United States Constitution is the "right to be let alone," which protects an individual's interest in avoiding the disclosure of personal information. ${ }^{134}$ In general, tenants maintain a right of privacy. In the context of landlord-tenant relationships involving persons suffering from mental illness, the landlord must be cognizant of the risk entailed when private facts (of illness or prior institutionalization) are publicly disclosed to other tenants. ${ }^{135}$ Dean Prosser characterized the interest harmed by this socalled public disclosure of private facts as reputation-in essence, an extension of defamation. ${ }^{136}$ Because a landlord probably cannot prevent harm to tenants from the criminal acts of fellow tenants already permitted in the complex by increasing security (which usually is intended to keep unauthorized strangers out), the only way to protect other tenants from this type of harm may be by disclosure of the dangerous tenant's criminal propensities. ${ }^{137}$

Finally, landlords may face additional problems in the investigation of prospective tenants if it is the child of the prospective tenant who has a record of previous criminal activity or

Rucker, 535 U.S. 125, 135, 122 S.Ct. 1230, 1236 (2002).

${ }^{134}$ Whalen v. Roe, 429 U.S. 589, 599, 97 S.Ct. 869, 876, 51 L.Ed.2d 64 (1977); City of Sherman v. Henry, 928 S.W.2d 464, 167 (Tex. 1996).

${ }^{135}$ White, Outing the Madman, 28 FORDHAM URB. L.J. at 804.

${ }^{136}$ William L. Prosser, Privacy, 48 CAL. L. REV. 383, 398 (1960).

${ }^{137}$ Saxer, “Am I My Brother's Keeper?”, 80 NEB. L. REV. at 553. See Christy E. Ford, Duty to Warn and Public Notification of the Release of Sex Offenders, 49 S.C. L. REV. 1131, 1134 (1998) (discussing the general duty to control or warn of the dangerous propensities of others and noting that "[e]ven the celebrated Tarasoff $v$. Regents of University of California holding has since been narrowed to a duty to warn only when a specific victim is identified"). 
who is on a list of sexual offenders. ${ }^{138}$ If the landlord screens only the parents for criminal records and checks the sex offender registry for the parents, the juvenile's information will not be revealed. ${ }^{139}$ Most jurisdictions protect a juvenile offender's records from public disclosure, in which case the information will not be publicly available to either the landlord or to the other tenants. ${ }^{140}$

\section{Statutes Prohibit Landlords from Refusing to Rent to Potential Tenants on the Basis of Mental Illness that Could Result in Criminal Activity}

Landlords may refuse to rent to individuals with criminal records. Generally, states consider facts concerning arrests and convictions to be public record. ${ }^{141}$ The far trickier issue is

${ }^{138}$ For an analysis of disclosure of juvenile records in public housing, see Kristin Henning, Eroding Confidentiality in Delinquency Proceedings: Should Schools and Public Housing Authorities Be Notified?, 79 N.Y.U. L. REv. 520, 524 (2004) (arguing that "policymakers should deny public housing authorities access to juvenile records under all circumstances, but should create a system whereby schools are granted limited access to those records. While sharing records with schools may be necessary to encourage and facilitate schools' collaboration in the rehabilitation of delinquent children and to address any real and immediate threat to students in the contained school environment, public housing authorities rarely have collaborated in rehabilitation and may be in a better position than schools to assume the risk of crime from unreformed juvenile offenders. Public housing authorities instead should rely on the juvenile and criminal justice systems to detain or incarcerate the most dangerous offenders and should look for other public safety measures to address crime in public housing communities.”)

${ }^{139}$ See Brian A. Snow \& William E. Thro, Redefining the Contours of University Liability: The Potential Implications of Nero v. Kansas State University, 90 EdUC. L. REP. 989 (1994) (criticizing a Kansas Supreme Court decision, Nero v. Kansas State University, 861 P.2d 768 (Kan. 1993), that found a university liable for failure to protect one student from criminal assault by another student, when the attacker had a criminal juvenile record). Some states, such as California allow for disclosure of certain juvenile records to secondary schools "to protect potentially vulnerable school staff and other students." Cal. Welf. \& Inst. Code § 827(b)(1).

${ }^{140}$ See, e.g., Tex. Fam. Code $\$ 58.001$, et seq. See also Saxer, “Am I My Brother's Keeper?”, 80 NEB. L. REV. at 565-66. See also 18 U.S.C. §§ 5038(a) to 5038(c) (federal Juvenile Delinquency Act prohibits unauthorized disclosure of juvenile records).

${ }^{141}$ See, e.g., Paul v. Davis, 424 U.S. 693, 713, 96 S.Ct. 1155, 1166, 47 L.Ed.2d 405 (1976) (no constitutional privacy right affected by publication of name of arrested but untried 
whether a landlord can refuse to rent to someone who exhibits tendencies that might lead one to believe he or she could commit criminal acts. If those tendencies are the result of mental illness, the answer likely is no. Certain statutes protect the mentally ill, even those individuals who may show the potential for violence, from any adverse action based on discovery of the fact of the mental illness or violent propensity.

The Fair Housing Amendments Act (FHAA) protects handicapped persons from housing discrimination. Under the Act it is unlawful:

(1) To discriminate in the sale or rental, or to otherwise make unavailable or deny, a dwelling to any buyer or renter because of a handicap . . . (2) [and] to discriminate against any person in the terms, conditions, or privileges of sale or rental of a dwelling, or in the provision of services or facilities in connection with such dwelling, because of a handicap. ${ }^{142}$

The Act defines as handicapped any person who has "a physical or mental impairment which substantially limits one or more of such person's major life activities," has "a record of having such an impairment," or is "regarded as having such an impairment."143 Under the FHAA, landlords have an affirmative duty to reasonably accommodate a person's handicap unless the landlord can show that the accommodation would impose an undue hardship. ${ }^{144}$

shoplifter); See also Robert R. Stauffer, Note, Tenant Blacklisting: Tenant Screening Services and the Right to Privacy, 24 HARV. J. ON LEGIS. 239 (1987).

${ }^{142} 42$ U.S.C. $\S 3604(t)$.

${ }^{143} 42$ U.S.C. § 3602(h); see also 24 C.F.R. § 100.201(a)(2) (2004) (discussing what is discriminatory conduct under the Act).

${ }^{144}$ United States v. California Mobile Home Park Mgmt. Co., 29 F.3d 1413, 1416-17 (9th Cir. 1994). The American Psychiatric Association's Diagnostic and Statistical Manual defines "serious" mental illness to include "(A) schizophrenia; (B) paranoid and other psychotic disorders; (C) bipolar disorders (hypomanic, manic, depressive, and mixed); (D) major depressive disorders (single episode or recurrent); (E) schizo-affective disorders (bipolar or depressive); (F) pervasive developmental disorders; (G) obsessive-compulsive disorders; and (H) depression in childhood and adolescence." See e.g., Tex. Ins. Code Ann. art. 3.51-14. In 
States have similar statutes. ${ }^{145}$ For example, in 1989, the Texas Legislature adopted the Texas Fair Housing Act which mirrors the federal Fair Housing Act. Thus, the Texas Fair Housing Act provides additional protection for tenants against discrimination if they have or are regarded as having a mental disability. ${ }^{146}$ Showing some awareness of the need for landlords to provide safe living environments, subsection (f) of that statute provides that "this section does not require a dwelling to be made available to an individual whose tenancy would constitute a direct threat to the health or safety of other individuals or whose tenancy would result in substantial physical damage to the property of others." As noted above, whether someone constitutes a "direct threat,"-i.e., whether someone in treatment for mental illness will go off his medications, or whether someone with no prior criminal inclination will move from minor neuroses to psychopathic behavior-will be very difficult to discern. ${ }^{147}$ "A landlord is not

addition, impairment of "major life activities" is a subject of continual litigation. See, e.g., Bryan P. Stephenson, Comment, I'm So Lonesome I Could Cry ... but Could I Sue?: Whether "Interacting with Others" Is a Major Life Activity Under the ADA, 31 PEPP. L. REv. 773 (2004).

${ }^{145}$ See e.g., Ariz. Rev. Stat. § 41-1491(5) (“'Disability’ means a mental or physical impairment that substantially limits at least one major life activity, a record of such an impairment or being regarded as having such an impairment. Disability does not include current illegal use of or addiction to any drug or illegal or federally controlled substance. Disability shall be defined as the term is defined by the Americans with Disabilities Act of 1990 (P.L. 101336)."); Ind. Code § 22-9.5-5-3 ("A person may not represent to any person because of race, color, religion, sex, disability, familial status, or national origin that a dwelling is not available for inspection for sale or rental when the dwelling is available for inspection."); $5 \mathrm{Me}$. Rev. Stat. Ann. § 4582 (same); Ark. Code Ann. § 16-123-314(b) (“A person shall not discriminate against any person in the terms, conditions, or privileges of sale or rental of a dwelling or in the provision of services or facilities in connection with the dwelling because of a disability of: (1) That person; (2) A person residing in or intending to reside in that dwelling after it is sold, rented, or made available; or (3) A person associated with that person.”).

${ }^{146}$ See Tex. Prop. Code $\S 301.025$.

${ }^{147}$ Cf. Apple v. Tracy, 34 Mass. App. Ct. 560, 613 N.E.2d 928, rev. denied, 416 Mass. 1102,618 N.E.2d 1364 (1993) (homeowner has no duty to neighboring minor sexual assault victim to protect from homeowner's guest - a sex offender who was on probation - because it 
competent to assess the dangerous propensities of his mentally ill tenants," and assessing whether a tenant might be subject to violent behavior against other tenants is difficult for even the best-trained mental health expert. ${ }^{148}$ Thus, courts should not place landowners in the position of investigating and acting on what they might perceive as an individual's potential to commit violent acts against cotenants.

\section{Twist \#3: The Impact of Gang Violence}

In Delgado v. Trax Bar \& Grill, the California Supreme Court dismissed in a single sentence the Court of Appeal's finding that alcohol-fueled bar brawls were insufficiently similar to a coordinated gang assault to be considered prior similar incidents for purposes of heightened foreseeability analysis. ${ }^{149}$ Instead, the court simply noted that prior similar incidents need not be nearly identical even though it ultimately agreed with the lower court's decision that Delgado had failed to produce sufficient evidence of prior similar incidents. ${ }^{150}$ It is unfortunate that the court glided over this point so blithely, because there are distinguishing features of gang violence that should make courts wary of lumping it together with "random" crime.

It is a sad fact of modern life that gang violence is present throughout California and the nation in ever-increasing quantities. ${ }^{151}$ Of the twelve cities nationwide with the highest number

would require ordinary citizens to make predictive assessments about probationers that they are unqualified to make).

${ }^{148}$ See Gill, 130 A.D.2d at 263.

${ }^{149}$ Delgado, 36 Cal. 4th at 245, 30 Cal. Rptr. 3d at 161.

${ }^{150}$ Id.

${ }^{151}$ John M. Hagedorn, Gang Violence in the Postindustrial Era, 24 CRIME \& JUST. 365, 378 (1998). 
of gang-related homicides, eight are in California. ${ }^{152}$ A 1998 Justice Department study estimated there were more than 28,700 gangs with 780,200 members nationwide. ${ }^{153}$

Concerned with the rising tide of gang violence, several states have enacted statutes specifically designed to respond to crimes committed by gang members. For example, California enacted several statutes comprising the California Street Terrorism Enforcement and Prevention Act (STEP Act). ${ }^{154}$ The impetus behind the STEP Act was the Legislature's recognition that

California is in a state of crisis which has been caused by violent street gangs whose members threaten, terrorize, and commit a multitude of crimes against the peaceful citizens of their neighborhoods. These activities, both individually and collectively, present a clear and present danger to public order and safety and are not constitutionally protected. ${ }^{155}$

The Act's express purpose is "to seek the eradication of criminal activity by street gangs."156

${ }^{152}$ Id. at 378 , Table 2. The four outside of California are Chicago, Cleveland, Kansas City, and Milwaukee. Id.

${ }^{153}$ U.S. Department of Justice, 1998 National Youth Gang Survey 12 (2000), cited in Kim Strosnider, Anti-Gang Ordinances after City of Chicago v. Morales: The Intersection of Race, Vagueness Doctrine, and Equal Protection in the Criminal Law, 39 AM. CRIM. L. REV. 101, 105 \& n.30 (2002).

${ }^{154}$ Cal. Penal Code $\S 186.20$, et seq. The STEP Act paired civil and criminal remedies, creating new substantive crimes and providing for civil injunctions and the use of publicnuisance law. The core provision of STEP criminalizes active, knowing participation in a criminal street gang (see Penal Code $\S 186.22$ (f)), and the willful promotion, furtherance, or assistance to the gang in committing a felony. Penal Code $\S$ 186.22(a). STEP also criminalizes the act of coercing participation in a street gang. Penal Code $\S 186.26$. Further, it provides for the issuance of injunctions and civil damages when the government identifies property that gangs had been using to advance their criminal activities, $\S 186.22(\mathrm{a})$, and for confiscation of firearms used in gang crime. Id.; see also Penal Code $§ 186.28$.

${ }^{155}$ Cal. Penal Code $\S 186.21$; Medina v. Hillshore Partners, 40 Cal. App. 4th 477, 481, 46 Cal. Rptr. 2d 871, 874 (1995).

${ }^{156}$ Cal. Penal Code $§ 186.21$; People v. Montes, 31 Cal. 4th 350, 354, 73 P.3d 489, 491, 2 Cal. Rptr. 3d 621, 623-24 (2003); see also People ex rel. Gallo v. Acuna, 14 Cal. 4th 1090, 1100, 
Part of the STEP Act provides sentence enhancements ranging from two to ten extra years in prison for crimes committed by gang members. ${ }^{157}$ Thus, a gang member who criminally discharges a firearm will be punished more severely than someone who commits the same crime but who does not belong to a gang. This difference in treatment does not violate the Equal Protection Clause because the a gang member is not similarly situated to a non-gang member. ${ }^{158}$ Experience shows gangs are large, organized groups that promote the use of violence to "protect" their territory, retaliate for acts of violence or "disrespect" by other gangs, and enhance both the stature of the gang and the individual within the gang. ${ }^{159}$

Gang members, acting individually, might attack rival gang members in order to increase their reputation in their own gang or in the eyes of the rival gang, or in retribution for a previous attack by the rival gang in their ongoing conflict. Maintaining respect and reputation also plays a role in gangs' organizational attacks on rival gangs. In addition, gangs acting as an organization might initiate a gun battle with a rival gang to consolidate control over drug territory or to expand into new territory. ${ }^{160}$

Law enforcement personnel and prosecutors are specially trained to handle gang violence

929 P.2d 596, 601-02, 60 Cal.Rptr.2d 277, 282-83 (1990) (graphic description of gang-infested neighborhood precedes decision upholding injunction provisions of the STEP Act).

${ }^{157}$ Cal. Penal Code $\S 186.22(b)(1)(A)-(C)$.

${ }^{158}$ People v. Gonzales, 87 Cal. App. 4th 1, 13, 104 Cal. Rptr. 2d 247, 255 (2001).

${ }^{159}$ Bart H. Rubin, Hail, Hail, the Gangs Are All Here: Why New York Should Adopt a Comprehensive Anti-gang Statute, 66 FoRDHAM L. REV. 2033, 2051-52 (1998).

${ }^{160}$ Paul J. Arougheti, Imposing Homicide Liability on Gun Battle Participants for the Deaths of Innocent Bystanders, 27 ColuM. J.L. \& Soc. ProBS. 467, 519-20 (1994) (citations and footnotes omitted). 
above and beyond the usual. Police departments have special units to combat gangs' criminal activities; ${ }^{161}$ counties and cities provide special services to at-risk youth to prevent them from joining gangs; ${ }^{162}$ and district attorneys' offices have lawyers who specialize in prosecuting gang members. $^{163}$

When those prosecutions get into court, procedural decisions are based on the wellknown fact that criminal activity by gangs is of a different sort than other types of crimes. In

${ }^{161}$ See Phelan A. Wyrick and James C. Howell, Strategic Risk-Based Response to Youth Gangs, 9 Juvenile Justice 20 (Sept. 2004) available at http://www.ncjrs.gov/pdffiles1/ojjdp/203555.pdf (last visited Sept. 22, 2005) (a publication of the federal Office of Juvenile Justice and Delinquency Prevention) (identifying means of combating youth "at-risk factors" associated with the individual, family, school, peer group, and the larger community). See also Stockton [California] Police Department Gang Unit, Gang Activity and Commonly Asked Questions, at http://www.stocktongov.com/police/pages/tipsabout gangs.htm (last visited Dec. 16, 2003); Austin [Texas] Police Department, Gang Suppression Unit, http://www.ci.austin.tx.us/police/gang.htm (last visited Sept. 22, 2005) ("Gang activity is more complex than it has ever been, encompassing a wide range of groups. The community and your police department now contend with juvenile street gangs, criminal prison gangs, and hate groups which statutorily meet the gang criteria.").

${ }^{162}$ The California Department of Justice administers the California Gang, Crime, and Violence Prevention Partnership Program which provides \$3 million annually in administrative costs and local assistance funding for community-based organizations and nonprofit agencies. Communities may receive funding for up to four years to implement programs to reduce gang and criminal activity and youth violence. California Attorney General's Crime and Violence Prevention Center, 1998 - 2002 California Gang Crime and Violence Grantee Recipients, at http://safestate.org/documents/gang\%20grant\%20gangs_grantee_recipients.pdf (last visited Dec. $16,2003)$.

${ }^{163}$ The Stanislaus District Attorney's Office has a Gang Suppression Unit with three prosecutors and one investigator and an investigative assistant that assigns each case to one prosecutor for "vertical prosecution." Stanislaus County District Attorney Annual Report (2001), at 7-8, available at http://www.stanislaus-da.org/PDF/ANNUALREPORT_1.pdf (last visited Dec. 16, 2003). See also Winifred L. Reed and Scott H. Decker, eds. Responding to Gangs: Evaluation and Research, National Institute of Justice (U.S. Dept. of Justice) (July 2002) (available at http://www.ncjrs.gov/pdffiles1/nij/190351.pdf (last visited Sept. 22, 2005) (collecting research papers describing and evaluating anti-gang programs in Nevada, Boston, San Diego, Orange County (California), Columbus, St. Louis, and Chicago, as well as nationwide trends toward gang suppression and prosecution). 
California, judicial notice is appropriate for "two matters of common knowledge: (1) that street gangs generally claim a 'home territory' and attempt to prohibit rival gang members from entering the area upon threat of severe physical injury, and (2) that gang activity spawns violence." ${ }^{164}$ Yet even while these facts are generally known, the nature and operations of gangs is considered outside an ordinary person's common knowledge, such that expert witnesses are frequently called into court to describe how gangs work and whether particular actions fit the gang mold. ${ }^{165}$

The axiom that "gangs are different" is reflected in several premises liability cases that involved gang violence. In Gregorian v. National Convenience Stores, Inc., ${ }^{166}$ the court of appeal held that a proprietor of an all-night convenience store may "reasonably anticipate that his place of business will be the target of armed robbers, the same cannot be said for a crime resulting from gang violence. This is especially true where, as in the case at bench, the premises has never been the focal point of gang activity.",167

In Medina v. Hillshore Partners, ${ }^{168}$ the court found that, as a matter of public policy, a landowner is not vicariously liable for gang-related assaults that occur on public sidewalks and

\footnotetext{
${ }^{164}$ Medina v. Hillshore Partners, 40 Cal. App. 4th at 481, 46 Cal. Rptr. 2d at 874 .

${ }^{165}$ See, e.g., People v. Gardeley, 14 Cal. 4th 605, 617, 927 P.2d 713, 720, 59 Cal. Rptr. 2d 356, 363 (1996), cert. denied, 522 U.S. 854 (1997), cited with approval in People v. Ochoa, 26 Cal. 4th 398, 438, 28 P.3d 78, 98, 110 Cal. Rptr. 2d 324, 349 (2001); People v. Olguin, 31 Cal. App. 4th 1355, 1370, 37 Cal. Rptr. 2d 596, 602 (1994) ("The use of expert testimony in the area of gang sociology and psychology is well established.").

${ }^{166} 174$ Cal. App. 3d 944, 220 Cal. Rptr. 302 (1985).

${ }^{167}$ Id. at 950, 200 Cal. Rptr. at 305 (decided under the Isaacs totality of the circumstances test), quoted with approval in Lopez v. McDonalds Corp., 193 Cal. App. 3d 495, 511, 238 Cal.Rptr. 436, 446 (1987).

${ }^{168} 40$ Cal. App. 4th at 486, 46 Cal. Rptr. 2 d at 877.
} 
streets even conceding that the congregation of gangs poses a foreseeable risk of harm to the public.

[T]he foreseeability of the criminal assault does not compel the ruling that landowners owe a duty to protect the public from gang-related crimes or assume a special relationship with members of the public who use adjacent streets and sidewalks. "If not ... concretely linked to a legal relationship the quest for foreseeability is endless because foreseeability, like light, travels indefinitely in a vacuum." 169

When members of rival gangs clash, "verbal taunting can quickly give way to physical violence and gun fire. No one immersed in the gang culture is unaware of these realities, and we see no reason the courts should turn a blind eye to them." 170

While Trax Bar \& Grill sought to distinguish run-of-the-mill bar brawls or other random crime from the type of gang violence that beset Michael Delgado, a recent California Court of

${ }^{169} I d$. (citing Newton v. Kaiser Foundation Hospitals, 184 Cal. App. 3d 386, 391, 228 Cal.Rptr. 890, 893 (1986)). See also Kolodziejzak v. Melvin Simon \& Associates, 292 Ill. App. 3d 490, 497-98, 685 N.E.2d 985, 990-91 (App. Ct. 1997), appeal denied, 176 Ill. 2d 575, 690 N.E.2d 1381 (1998) (property management company was not put on notice of likelihood that gang member would enter strip mall premises with a gun and shoot innocent person, where there were no incidents of gang intimidation, gang-related violence, or brandishing of any weapons by gang members on premises; report of armed robbery in one tenant's stores and strong-armed robbery were not linked to gang activity, report of man with gun concerned incident that occurred off premises, and no gang related incidents involved violence).

${ }^{170}$ People v. Montes, 74 Cal. App. 4th 1050, 1056, 88 Cal. Rptr. 2d 482, 486 (1999). Delgado is distinguished from Claxton v. Atlantic Richfield Co., 108 Cal. App. 4th 327, 133 Cal.Rptr.2d 425 (2003), in which gang violence was prevalent at the gas station at which Mr. Claxton was assaulted. The court correctly held that where a commercial business is the site of multiple violent and criminal acts and gang-related activity, the fact that those prior acts were not motivated by racial animus does not distinguish them from a violent personal attack motivated by hatred of the victim's race rather than hatred of the victim's gang-affiliation or lack thereof. Id. at 338-39, 133 Cal. Rptr. 2d at 433-34. 
Appeal decision addressed the issue from the other perspective - when the landowner is aware of gang members, and their violent tendencies - on the property. In Castaneda v. Olsher, ${ }^{171}$ gang members were known to congregate in several trailers in a mobile home park, including the trailer on Lot 23. A teenager who resided in an adjacent trailer to Lot 23 was shot one night by a gang member. ${ }^{172}$

The Castaneda court distinguished Ann M. and Sharon P. precisely because this case involves a gang shooting, which the court described as "qualitatively different" from cases where "the crime in question is random and unexpected."173 When crime is random, the court noted, the criminal acts generally are considered to be unforeseeable in the absence of prior similar acts occurring on the property. However, the court explicitly found that "[g]ang-related crimes are different from random criminal acts of third parties. It is well known that criminal and often violent activities are inherent to the gang lifestyle."174 The court held:

Where, as here, the property owner knows that gang members are congregating on his property and that gang activity and gang-related crimes are occurring there, a gang-related shooting is much more foreseeable than is a random violent criminal act. For this reason, courts may more readily impose on a landlord a duty to attempt to protect tenants from gang violence attributable to the known presence of gang members and gang activity on the landowner's property than a duty to protect people from random criminal acts by an otherwise random and transient third party. When a landlord is on notice of the presence of gang members and gang activity on his property, it is reasonable to expect the landlord to make efforts to increase security measures on the premises. This could be done in any number of ways, including increasing the security presence to more than a property manager and her son, providing security personnel with specialized training in how to identify and deal with potentially dangerous situations,

171 _ Cal. 4th _, 33 Cal. Rptr. 3d 827 (Cal. App. 2005).

${ }^{172}$ Id. at 830.

${ }^{173}$ Id. at 836 .

${ }^{174} \mathrm{Id}$. 
imposing and enforcing strict rules as to resident conduct in common areas, or providing a means by which to warn residents of troublesome areas. Such efforts could also include simply ensuring that the existing lighting in the Park is maintained in working order. ${ }^{175}$

An intermediate appellate court in New Jersey also recently addressed some of the questions presented by gang violence. In Kuehn v. Pub Zone, ${ }^{176}$ three members of a motorcycle gang called the Pagans, who had a reputation for engaging in random acts of violence, entered a Bar, had a couple drinks, and then brutally attacked another patron in the restroom, severely injuring him. The bar had a policy of denying entrance to gang members wearing colors (insignia declaring their membership in a particular gang). The bar was aware that the three bikers were Pagans, but permitted them to enter the Bar because they were not wearing colors.

In considering whether the attack on the patron was foreseeable, the court asked, "(1) was it foreseeable that Pagans, however dressed, would engage in random acts of violence, and if so, (2) did the fact that the Pagans were wearing identifying colors make it more foreseeable to tavern staff that they, rather than other customers, would attack randomly?" ${ }^{177}$ The court chose to consider the Pagan's colors simply as an identifier that provide information to a knowledgeable bar owner so that the owner could categorize patrons as either dangerous or non-threatening and act accordingly. ${ }^{178}$

${ }^{175}$ Id. at 837 (footnote omitted) (emphasis added).

${ }^{176} 364$ N.J.Super. 301, 835 A.2d 692 (N.J. Super. A.D. 2003).

${ }^{177}$ Id. at 310,835 A.2d at 698.

${ }^{178}$ Id. The court further noted that the evidence showed only that the Pagan gang was known for acts of random violence which was not necessarily connected to their wearing colors. Id. 
New Jersey employs the "totality of the circumstances" test. ${ }^{179}$ Under the circumstances, the court found that the bar had a duty to take reasonable precautions against the danger posed by the Pagans as a group. The court acknowledged that there was no evidence suggesting that any of the particular Pagans present in the Bar were likely to assault anyone at this particular time. Nonetheless, because the gang was collectively known to the bar owner to engage in random violence, the owner had knowledge that "there was 'a likelihood of conduct on the part of third persons in general' that was 'likely to endanger the safety' of a patron at some unspecified future time. A 'duty to take precautions' against the endangering conduct thus arose."180 The court further grounded its decision on "[f]airness and public policy," asserting that "no one would argue that gang violence should be tolerated or that preventable violence should be permitted to occur."181 These public policy grounds, while stating aspirational goals for society, do not actually support placing a duty on the bar owner via a premises liability claim for negligence. The court's formulation of the public policy would just as easily support a conclusion that gang members must be denied entry to bars or that a bar owner has a duty to phone the police upon noting simply the presence of gang members on the premises.

The impact of gang violence also raised questions in Morris v. De La Torre, ${ }^{182}$ a California Supreme Court decision issued the same day as Delgado v. Trax Bar \& Grill. In Morris, five friends went to a taco shop located in a San Diego strip mall at 1:00 in the morning. Three of the group, including Charles Morris, who had an upset stomach and did not plan to eat,

${ }^{179}$ Id. at 312,835 A.2d at 698.
${ }^{180}$ Id.
${ }^{181}$ Id.
${ }^{182}$ Morris, 36 Cal. 4th 260, 113 P.3d 1182, 30 Cal. Rptr. 3d 173. 
stayed in the car while the other two went inside to get some food. ${ }^{183}$ While they were waiting, some gang members led by Richard Cuevas arrived in the parking lot. After exchanging words with Morris (who was not a gang member), Cuevas ran into the taco shop demanding a knife, pushed his way to the kitchen area behind the counter, grabbed a knife, ran back to the parking lot and stabbed Morris. ${ }^{184}$ Morris fled, but Cuevas caught up to him and stabbed him again. During Morris's flight, one of his friends called $911 .^{185}$ The police arrived about four minutes later. ${ }^{186}$ Cuevas was arrested six months after the assault and convicted of attempted murder. ${ }^{187}$ Morris sued on a theory derived from the earlier case of Kentucky Fried Chicken of Cal., Inc. v. Superior Court, ${ }^{188}$ which held that when ongoing criminal conduct occurs in the presence of a restaurant proprietor, there is a duty to warn or "take such appropriate action as is reasonable under the circumstances to protect patrons" and invitees. ${ }^{189}$ The court agreed with Morris that the taco shop owner (via his employees) did have such a duty, and that a jury must decide whether the owner breached that duty when his employees failed to make a 911 telephone call to

\footnotetext{
${ }^{183}$ Id. at 266, 30 Cal. Rptr. 3d 177.

${ }^{184}$ Id.

${ }^{185}$ Morris, 36 Cal. 4th at 267, 30 Cal. Rptr. 3d at 178.

${ }^{186} \mathrm{Id}$.
}

${ }^{187}$ See Greg Moran, Court order limits activities of gang in south, SAN DIEGO UNIONTRIBUNE, 2002 WLNR 11144844 (Feb. 28, 2002) (noting conviction and further noting that, upon his release from prison, Cuevas will be covered by the terms of an injunction obtained by the San Diego Office of the District Attorney prohibiting members of his gang from congregating in a particular area of San Diego. The injunction also bans a variety of activities such as making gang signs, wearing certain kinds of clothing, possessing drugs, alcohol or weapons, making loud noises and intimidating the public).

${ }^{188} 14$ Cal. 4th 814, 59 Cal. Rptr. 2d 756, 927 P.2d 1260 (1997).

${ }^{189}$ Id. at 823, 59 Cal. Rptr. 2d at 762, 927 P.2d at 1266. 
summon aid for Morris. ${ }^{190}$

The court acknowledged the gang violence and intimidation as an abstract consideration that might, in some cases, impact an employee's willingness to call 911, noting that "the record would support the conclusion that an employee in similar circumstances reasonably might decline to call 911 out of fear of gang retaliation." ${ }^{\text {"191 } 608 ~ N . E .2 d ~ 499, ~} 504$ (Ill. App. Ct. 1992) (same); United States v. Santiago, 46 F.3d 885, 890 (9th Cir. 1995) (same; noting also that evidence of witness's fear of retaliation, without specifying any particular acts of intimidation, does not qualify as Fed. R. Evid. 404(b) evidence). However, the court would not state that, as a matter of law, that "any of the [taco shop's] three employees failed to call 911 because of an actual fear of Cuevas specifically or of gang retaliation generally." 192

Yet gang retaliation remains a real threat. In United States $v$. Diaz, ${ }^{193}$ the district court judge assigned great weight to the testimony of Mikail Ali, an employee of the San Francisco Police Department who qualified as an expert witness on African-American criminal street gangs

${ }^{190}$ Morris, 36 Cal. 4th at 264, 30 Cal. Rptr. 3d at 176.

${ }^{191}$ Id. at 277, 30 Cal. Rptr. 3d at 186 (emphasis original). Evidence about gang retaliation, including an individual's fear of being the subject of such retaliation, is admissible to explain a witness's change in statement or reluctance to testify. See e.g., People v. Skinner, 53 P.3d 720, 724 (Colo. App. 2002) (no error found after evidence admitted establishing "code of silence" between inmates in Department of Corrections; testimony of witnesses regarding fear of retaliation for being a "snitch" was relevant to explain why the victim and other witnesses had given conflicting statements); People v. Sanchez, 58 Cal. App. 4th 1435, 1450, 69 Cal. Rptr. 2d 16, 24 (Cal. App. 1997) (evidence that witness is afraid to testify and fearful of gang retaliation is relevant to credibility of witness; it is not necessary to show threats against witness were made by defendant personally); People v. Maldonado, 240 Ill. App. 3d 470, 504, 181 Ill. Dec. 426, 431 ,

${ }^{192}$ Id. at 278, 30 Cal. Rptr. 3d at 187. There was also evidence presented that the employees might have been illegally present in this country and therefore hesitant to call the authorities. Id. and at n.7.

${ }^{193} 2005$ WL 1575191 (N.D. Cal. Jun. 30, 2005). 
in San Francisco. Sergeant Ali testified, "I am personally aware of over 100 instances in which civilian witnesses have informed me that they were too afraid of gang retaliation by members of the DBG [Down Below Gangsters] to testify or cooperate with law enforcement." ${ }^{194}$ Particularly when many employees of fast food or counter restaurants are teenagers, ${ }^{195}$ the court almost certainly underestimated the peril such employees could face by contacting law enforcement authorities while the crime is still ongoing.

\section{CONCLUSION}

Courts should not attempt to assist crime-fighting efforts "by enlisting property owners in the battle through the threat of tort liability." ${ }^{196}$ If the courts are concerned about spreading the cost of injuries sustained due to criminal acts over a broader population segment, then the most logical response would be to spread the cost among members of the whole community. ${ }^{197}$ Many states attempt to mitigate some of the financial burdens thrust upon many crime victims by providing funds to cover their medical expenses, lost work time, and property loss and

${ }^{194}$ Id. at $* 2$.

${ }^{195}$ In a survey of teens working 1996-98, the United States Department of Labor found that 2.9 million youths aged 15 to 17 worked during school months, and 4.0 million worked during the summer months. U.S. Dept. of Labor, Report on the Youth Labor Force at 30 (Nov. 2000) http://www.bls.gov/opub/rylf/pdf/chapter4.pdf (last visited Sept. 22, 2005). "Four of the ten most common detailed industries in which employed male youths worked and six of the top ten industries in which female youths worked were in retail trade. Eating and drinking places and grocery stores were the largest employers of both male youths (accounting for 31 and 14 percent, respectively) and female youths (33 and 10 percent)". Id. at 36. See also People v. Castellano, 140 Cal. App. 3d 608, 611189 Cal. Rptr. 692, 693 (Cal. App. 1983) (describing hold-up at fast food restaurant at 10:00 p.m. when only four teenage employees were on duty).

${ }^{196}$ Stephen D. Sugarman, Judges as Tort Law Un-Makers: Recent California Experience with "New" Torts, 49 DePaul L. ReV. 455, 459 (1999).

${ }^{197}$ George Bair South, The Duty to Protect Customers from Criminal Acts Occurring off the Premises: The Watering-Down of the "Prior Similar Incidents" Rule, 19 HOFSTRA L. REV. 1271, 1379 (1991). 
damage. ${ }^{198}$ In 1965 , California became the first state in the nation to create a crime victim compensation program. ${ }^{199}$ The other 49 states and federal government followed suit. ${ }^{200}$ This type of fund is a more fair, and more efficient, means of providing support and compensation to crime victims. ${ }^{201}$

Judicial requirements of additional security always have the greatest impact in lowincome, high-crime areas. When a landowner's duty to protect is expanded, there are identifiable societal costs that go along with it:

Since protection costs money, how would a business operating on a small profit margin fulfill its obligation in a high-crime area? If business owners absorb the

${ }^{198}$ For example, in 1979, Texas created a crime victim compensation program, Tex. Code Crim. Proc. Ann. art. 56.31. Last year, the program received almost 35,000 applications and distributed a record $\$ 71.2$ million in compensation benefits. Greg Abbott, Crossroads: Crime Victims Compensation Program 2003 Annual Report(2003) (http://www.oag.state.tx.us/AG_Publications/pdfs/2003cvc_annual.pdf) (visited June 24, 2004).

${ }^{199} 1965$ Cal. Stat. 1549. See Aileen Adams and David Osborne, Victims' Rights and Services: A Historical Perspective and Goals for the Twenty-First Century, 33 MCGEORGE L. REV. 673, 675 (2002) (citing United States Department of Justice, Office for Victims of Crime, New Directions from the Field: Victims' Rights and Services for the 21 st Century 325 (May 1998)). The California Victim Compensation Board paid out a record 124 million dollars in claims in fiscal year 2001-2002. Id; see also Cal. Const. art. I, § 28 (mandating restitution to victims from the individual convicted of the crime).

${ }^{200}$ Id. See, e.g., Victims of Crime Act of 1984, 42 U.S.C. $\$ \S 10601-10604$. Examples of state statutes include Ala. Code $\S 15-18-67$, Iowa Code $§ 910.2$, and Mich. Comp. Laws Ann. $\S$ 780.766(3). Victim compensation programs provide victims compensation from the government and not the criminal, whether the criminal is apprehended or not. David L. Roland, Progress in the Victim Reform Movement: No Longer the "Forgotten Victim", 17 PEPP. L. REV. 35, 43 (1989).

${ }^{201}$ Recently, several states are augmenting their crime victim compensation programs via "split-recovery" legislation that requires a certain percentage of punitive damages awards to be channeled into the programs. See, e.g., Indiana Code section 34-4-34-6 (plaintiff keeps $25 \%$ of punitive damages and deposits $75 \%$ with state treasurer for crime victim fund); Ore. Rev. Stat. 18.540 (allocating $60 \%$ of each punitive damages award in Oregon to the state's Criminal Injuries Compensation Account). Compare Vernon's Ann. Mo. Stat. 537.675 (requiring 75\% of punitive damages to go to state's tort victim's compensation fund). 
high cost of protection by raising the price of their goods and services, how will the poor (who most often reside in areas where the incidence of crime is greatest) be able to meet their basic needs given the minimal financial resources available to them? In all practicality, would they not be singled out as the ones to pay for their own police protection? Would it not be more economical for businesses to close their doors and relocate to "safer ground"? If so, how would indigent members of that community who lack adequate means of transportation be able to obtain needed goods and services? ${ }^{202}$

Businesses can only absorb a certain amount of additional cost before passing those costs onto the customers they serve. If the goods become too high-priced, they will not sell and the business will close. Or if the business decides that it cannot recoup its costs, then it simply will find another location where the clientele can afford the higher prices. This has a further economically depressing effect on residents of low-income areas who themselves wish to become entrepreneurs but find the entry costs too high. Because these entrepreneurs would hire other residents, the total effect of a business precluded from opening is increased joblessness; fewer available, affordable services; and a neighborhood the remains mired in economically depressed circumstances.

The recent California decisions will tend to lead to this gloomy conclusion. The Delgado and Morris decisions conclude that if a criminal act is still in the future, the court will apply the prior incidents rule to determine whether the property owner had a duty to have certain types of security. But once the crime commences, the court shifts to an ad hoc "totality of the circumstances" review. This places too great a burden upon landowners and business owners because the court eschewed any type of clear rule in favor of a sliding scale that actually slides on more than one axis. The level of the duty shifts not only depending on evidence of prior

${ }^{202}$ Sigfredo A. Cabrera, Negligence Liability of Landowners and Occupiers for the Criminal Conduct of Another: On a Clear Day in California One Can Foresee Forever, 23 CAL. W.L. REV. 165, 188 (1987). 
criminal acts on the premises, but also shifts depending on whether a crime is in the future, imminent, or ongoing. Unfortunately, criminal activity moves from one stage to the next in a matter of minutes. When Delgado walked in the bar, the assault was in the future; arguably it became imminent when he attracted the attention of the thug who engaged him in a staring contest; it was ongoing as soon as the assault commenced. The facts in the Morris case present a similar situation that was, if anything, even more fast-moving. The court had suggested in earlier cases - such as Ann M. and Sharon P. - that heightened scrutiny was the appropriate standard for reviewing premises liability actions based on the criminal acts of third-parties. Many states still apply that analysis. Yet the Delgado and Morris decisions backed away from that straightforward - and fair - rule, with the result that courts will now be in the business of second guessing the reasonableness of property owners and their employees during an ongoing criminal act. 